DIW BERLIN

Discussion

Papers

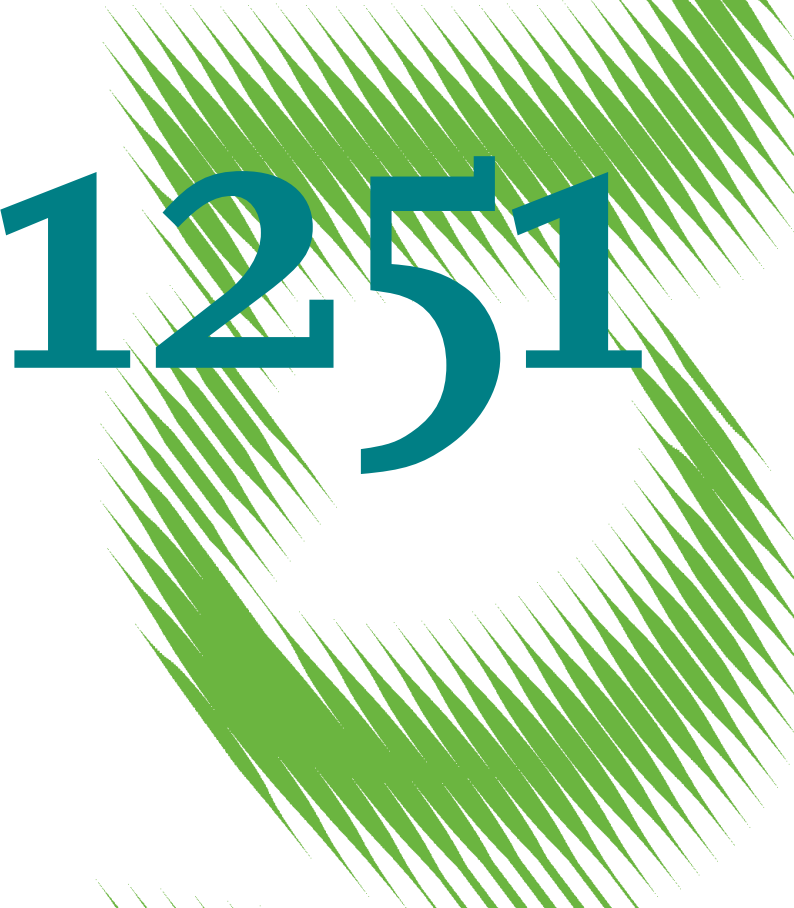

Market Access and Child Labour

Survey Evidence from Rural Uganda 
Opinions expressed in this paper are those of the author(s) and do not necessarily reflect views of the institute.

IMPRESSUM

(C) DIW Berlin, 2012

DIW Berlin

German Institute for Economic Research

Mohrenstr. 58

10117 Berlin

Tel. $+49(30) 89789-0$

Fax +49 (30) $89789-200$

http://www.diw.de

ISSN print edition $1433-0210$

ISSN electronic edition 1619-4535

Papers can be downloaded free of charge from the DIW Berlin website:

http://www.diw.de/discussionpapers

Discussion Papers of DIW Berlin are indexed in RePEc and SSRN:

http://ideas.repec.org/s/diw/diwwpp.html

http://www.ssrn.com/link/DIW-Berlin-German-Inst-Econ-Res.html 


\title{
Market Access and Child Labour: Survey Evidence from Rural Uganda ${ }^{1}$
}

\author{
Tony Muhumuza \\ German Institute for Economic Research (DIW Berlin) \\ tmuhumuza@diw.de
}

\begin{abstract}
The study analyses the relationship between access to rural product markets and the extent and nature of child labour. It is built on the view that if physical markets can shape rural development through, for instance, influencing prices, household production decisions and employment, the associated activity growth could increase child labour. Using household survey data from Uganda, I find that children increase time in domestic work when local product markets are distant, while their time in economic activity declines. A similar pattern is observed for the incidence of child labour. The likelihood of child labour in domestic activity increases for each extra hour of travel to the market, while child labour in economic activity declines. This could reflect the possibility that households may switch child work from market-oriented activities to domestic work when they are remotely located from markets. Results confirm findings from earlier cross-country studies that access to product markets may be detrimental to children. Second, they demonstrate that the effect of the markets varies, depending on the age of children, as well as the nature of the work they engage in.
\end{abstract}

Key words: Child labour, market access, Uganda, JEL classifications; J22, J82, 012

\footnotetext{
${ }^{1}$ I acknowledge valuable comments from Tilman Brück, Pamela Campa, Damir Esenaliev, Veronika Hümmer, Daniel Kemptner, Antje Kröger, Jan Markus, Kati Schindler, Susan Steiner, Marc Vothknecht, Sindu Workneh and participants of the $15^{\text {th }}$ IZA European Summer School in Labour Economics. I am grateful to the Uganda Bureau of Statistics (UBoS) for granting access to the data. I also acknowledge financial support from the German Academic Exchange Service (DAAD). The usual disclaimer applies.
} 



\section{Introduction}

This paper analyses the relationship between market access and child labour. In particular, the extent to which proximity to product markets influences participation of children in domestic and economic activity is investigated. According to the 2009 estimates of the ILO, about 215 million children in the world are engaged in child labour (IPEC, 2012). The practice is prevalent in developing countries, with the highest number in Asia (113.6 million), followed by Africa (65.1 million). In relative terms, the incidence of child labour is highest in Sub Saharan Africa, with 25\% of the children and adolescents working, compared to 13\% in Asia and the Pacific, and 10\% in Latin America and the Caribbean. There is considerable evidence that this widespread practice is one of the greatest threats to sustainable development, owing to its short-term and long-term effects on schooling (Betcherman et al., 2004; Kruger, 2007; UCW, 2008), health (Gustafsson-Wright and Pyne, 2002; UCW, 2008), and income (Ilahi et al., 2001), among other known drivers of development.

In rural areas of developing countries, where agriculture is the mainstay, children have been widely used to supplement adult labour in a variety of tasks (Jacoby and Skoufias, 1997). In locations close to urban areas, they increasingly participate in a range of economic activities such as the sale of household products and working for a wage (Fafchamps and Wahba, 2006). Although light activities are acceptable for child development (IPEC, 2011), some conditions could prevail within the households, or external environment such that children may work in risky activities, or for the duration that impedes their physical and psychological development. For instance, insufficient adult labour in the household may induce households to supplement adult time with child work (Murphy and Tamura, 1990; Rosenzweug and Evernson, 1977). The incentive of households to supply more labour could, in part, stem from the presence of profitable economic activities. For instance, markets could be functioning well, such that households highly value child time in the production of goods for the market, or use children as substitutes for adults in domestic work (Ranjan, 2011). Market opportunities may thus affect the extent of child labour by influencing production decisions and labour allocation in households.

While the analysis of the effect of market access on households is growing ${ }^{2}$, its link to child labour has only been remotely addressed. A few studies on child labour have rather

\footnotetext{
${ }^{2}$ See, for instance, Minten (1999) on productivity; Fally et al. (2010) on wages; Dercon and Hoddinott (2005) on household welfare.
} 
emphasised the effect of access to international markets (Jafarey, 2002; Ranjan, 2001). The major contribution to child labour literature at the micro level is a study by Fafchamps and Wahba (2006) that proxies market access with closeness to urban centres. Although proximity to urban locations could relate to market orientation, some markets, for instance product markets, have also been seen to prevail in distant locations (Afeichena and Ogunkola, 2000; Eff and Jensen, 2007; Udosen and Adams, 2009). Afeichena and Ogunkola argue that rural product markets of whatever form are vital for development. Thus, focusing on how close households are to urban areas is likely to be less informative, if relevant markets exist also in rural areas. In addition, urban locations may capture other characteristics, such as education, health and credit facilities, such that the effect of physical markets may be difficult to isolate.

Using a household survey for Uganda, this paper empirically tests whether proximity to local product markets has a bearing on the likelihood to engage in child labour and the intensity of child work (measured in hours of work). ${ }^{3}$ Focusing on different market types in rural areas, I hypothesise that proximity to product markets might be detrimental to children by increasing competition for the time they could have spent on activities that are vital for their development.

The paper contributes to the literature on child labour in three dimensions: First, I study the effect of access to product markets on child labour at the micro level. Second, I disaggregate market types depending on the volume and frequency of transactions. Third, I use a model that analyses simultaneously, the decision to engage in child labour and the intensity of child work

I find that the intensity of child work in domestic activity, regardless of child labour status, increases when daily consumer markets of limited assortments are distant from the village centre. Similar findings were obtained for local periodic markets. However, their time spent in economic activity declines with travel time to these markets. A similar pattern is observed for the incidence of child labour. The likelihood of child labour in domestic activity increases, but declines for economic activity, for an extra hour of travel to the market. This could be a reflection of the possibility that remotely positioned households may switch child

\footnotetext{
${ }^{3}$ Work for a child may constitute child labour if it is hazardous, or is executed for a duration that is beyond the time officially recommended for children of a specified age category. I define this concept in detail in section 2.
} 
work from market-oriented activities to domestic work. This result mirrors the findings in Fafchamps and Farhad (2003) that isolation from markets may keep households in a cycle of subsistence production. The effect of market access is more pronounced for older children, but the burden seems to be highly borne by girls, for all ages.

The paper is structured as follows. The next section discusses related literature. Section 3 provides an overview of the child labour situation in Uganda. Section 4 describes the structure of rural product markets in Uganda. The data are discussed in section 5. Section 6 discusses the model of child labour and market access. Section 7 presents descriptive evidence and regression results, and conclusions are made in the last section.

\section{Literature review}

\subsection{Access to markets and child labour}

Development partners are increasingly advocating investments that improve access to markets in order to stimulate productivity and improve household welfare. Market access enhances productivity in many ways: households can reliably sell more output at competitive prices, which may induce them to invest in profitable activities (Minten, 1999). Markets are also associated with increases in wages, both in the agricultural and in non-agricultural sectors (Redding and Venables, 2004). For households that supply labour, an increase in wages stimulates growth in income (Dercon and Hoddinott, 2005). Households can also access productive inputs at affordable prices. The resulting intensification of input use may increase technical efficiency (Bagamba, 2007).

There is substantial evidence that households with access to markets are more likely to increase participation in non-farm activities (Fafchamps and Forhad, 2003; Fafchamps and Shilpi, 2003; Hou, 2011). However, Barrett et al. (2001) argue that this shift doesn't necessarily imply that households will move out of farming. The variation in prices and differences among households could result in variability in farm and non-farm activities, thus creating differences in portfolio choices. Yao (2003) notes that for some households, markets may instead facilitate diversification within agriculture. On the other hand, isolated households may not interact with the market, but instead continue to engage in subsistence production (Fafchamps and Forhad, 2003). Fafchamps and Shilpi (2005) find that households closer to urban locations reduce time spent on household chores, indicating a shift towards the market. 
Benefits from market access could vary across households, due to the different levels of endowment. While better-off households might find it easier to diversify into farm or nonfarm activities, poorer households may instead be pushed into unskilled off-farm labour activities (Barrett et al., 2007). Households that access improved product markets are also better placed to put their hitherto under-utilized resources to use. Alternatively, they could reallocate the available resources to engage in market-oriented activities (Dercon and Hoddinott, 2005; UNCTAD, 2008). For poor and labour-constrained households, children could be a potential resource.

The decision to involve children in work may not be a desired option, given the evidence that parents care about their children's welfare (Basu and Van, 1998). Ideally, they would prefer to postpone child work against children's future earnings. However, individuals possess different levels of ability. For each level, there exists an income threshold, such that parents who fall below a certain threshold may have limited options for keeping their children out of work (Ranjan, 2001). This may be partly compounded by insufficient labour within the household to perform necessary tasks (Nugent, 1985; Wolpin, 1984). Such a scenario could cause households to highly value child time in production to an extent that is pareto inferior to what they would have chosen if labour was sufficient.

Child work can take one of two forms. Some households value child time in household chores such as childcare, collecting wood or cooking, where it may complement or substitute adult labour. Alternatively, children may be called upon to contribute to household labour in economic, including farming tasks to meet demand that arise from market access. Fafchamps and Wahba (2006) note that access to markets, proxied by closeness to urban locations induces households to engage children in economic activities, particularly wage employment. If households were in a position to hire labour, the effect of market access on child labour would be lessened. However Leinyuy (2008) goes further in arguing that family enterprises that are unable to hire labour may employ their children when market conditions improve, in order to meet the resulting increase in demand.

Child labour can persist if there exist markets for products in which children are engaged. In light of this notion, at the international level, Ranjan (2001) advocates limiting access to markets for such products through trade sanctions, while Grossmann and Michaelis (2007) suggest firm-specific tariff rates. The idea is that a decline in the exports of such products could reduce the demand for children's time. On the other hand, studies against sanctions posit that such action could lower the wages that working children obtain, exerting 
further income constraint on poor households (Edmonds and Pavcnik, 2005; Jafarey, 2002). This could instead increase child labour. This argument concurs with Basu and Van (1998), who contend that just as higher wages could motivate households to withdraw children from school, low wages could leave poor households with limited alternatives to child labour. A cross country study by Cigno et al. (2002) does not find any evidence of an increase in child labour with trade openness. Instead, openness is seen to reduce child labour.

It is evident from the literature that markets play an important role in influencing household behaviour regarding work allocation to children. However, while it sheds light on the effect on children with respect to trade openness, there are limited accounts describing how child labour is affected by local market conditions. For rural households in developing countries, local markets are vital for livelihoods, and may matter more than international markets, if transactions in the domestic market are significant.

\subsection{Defining child labour}

The ILO has been at the forefront of the campaign to develop a universally accepted definition of child labour. The first ILO convention of 1919 set the minimum age at 14 years for children working in an industrial setting. Over time, the definition has been revisited to cover a wide spectrum of activities and settings. For instance, the 1973 ILO convention (138) provides the most comprehensive and authoritative international standards on a minimum age for admission to employment or work (ILO, 1973). The basic yardstick is that the minimum age for entry into employment or work should not be lower than the age of completion of compulsory schooling in the respective countries. As a result, different countries have specified their own minimum age, depending on their internal social and economic structures.

A more comprehensive approach was reached in the United Nations Convention on the Rights of the Child (CRC) in 1979. Child labour was defined based on how activities, regardless of their nature, affect the welfare of the child. In 1999, the ILO adopted this principle through Convention 182 on the worst forms of child labour (ILO, 1999). Activities prohibited under this framework include those that amount to slavery; prostitution and pornography; illicit activities such as drug trafficking; or work that is likely to affect the health or morals of the child. Taken in their totality, these conventions imply that work should not be hazardous to the child's health or physical, mental, moral, or social development. The challenge with these provisions is the difficulty of differentiating between the various forms of child work. 
Currently the ILO's Statistical Information and Monitoring Program on Child Labour (SIMPOC) defines children as labourers if; they are aged below 12 years and engaged in economic activities for a least one hour a week, aged 12-14, and engaged in these activities for at least 14 hours per week, aged 15-17 years and engaged in economic activities for at least 43 hours per week, or below 18 and involved in work that is regarded as hazardous (IPEC, 2002). These definitions pay less attention to domestic work. Exclusion of domestic activities could result in social exploitation if this impedes the right to leisure or schooling. It may also lead to significant gender bias, since girls participate more in household chores than boys do (Guarcello et al., 2006; Lyon and Valdivia, 2010). The one-hour threshold for children below 12 years could also be questioned. One hour in a reference week, which converts to an average of about 9 minutes per day, may be very low to categorise a child as a labourer, if such activities are not hazardous.

The United Nations Children's Fund (UNICEF) expanded the ILO definition by including a 28-hour threshold for domestic work. This approach has been mostly applied by studies under the Understanding Child Work (UCW) programme (see, for instance, Gibbons et al., 2005; Guarcello and Lyon, 2004). Following this expansion, a child is a labourer if it is aged below 12 and engaged in economic activities for at least one hour, or at least 28 hours in chores, or aged 12-14 and performed economic work for at least 14 hours, or chores for at least 28 hours during the last week, or aged 15-17 and worked for at least 43 hours, or under 18 years and engaged in hazardous activities.

The difficulty with reconciling the two definitions is how to categorise the status of children in cases of variants of thresholds. For instance, using this definition, it is practically difficult to categorise a 12-to-14-year-old child who performed economic activities for 10 hours (below the 14 hour ILO threshold) and domestic work for 20 hours (below the 28 hour UNICEF threshold), which when combined, could constitute child labour.

\section{Child labour in Uganda}

Child labour is a common phenomenon in Uganda. In 2001 the country registered a total of 2.7 million economically active children, with more than half aged 10-14 years, and one third below 10 years (IPEC, 2001). By 2005, 3.8 million children (32\%) were working, of whom 1.7 million (16\%) were classified as child labourers, in both domestic and economic activities (ILO, 2007). In 2009, the number of children engaged in economic activities alone rose to 2.7 million (25.4\%), with the highest proportion (34.4\%) being children aged 5-11 (UBoS, 2010). 
The latest interagency report on child labour (UCW, 2010) indicates that the proportion of child labourers in the country is one of the highest in Sub Saharan Africa.

The incidence of child labour has reportedly been compounded by a number of factors. One such factor has been the HIV/AIDS pandemic that left behind millions of orphans (UBoS, 2003; UCW, 2010). The prolonged armed conflict in the northern region of the country, chronic poverty, and cultural practices that result in girls seeking employment in urban areas and boys working in household farms and enterprises, have also contributed to the high proportion of child labourers (Ssewanyana, 2009; IPEC and UBoS, 2001). In 2005, the Ministry of Finance (MFPED, 2005) cited as important drivers: the inadequacy of schools, parents valuing children's remunerative work above school as a way of preparing them for adulthood, and children's own desire to earn their own income. Studies on the nature and prevalence of child labour in the country have identified rural areas as the most affected. The school drop-out rate in rural areas has been found to be high partly because children are required to help in farming to supplement household income and earn money for school fees (IPEC and UBoS, 2001). Reports by Kyomuhendo et al. (2004) and the ECLT foundation (2007) indicate that a large number of child labourers are engaged in economic activity such tobacco and coffee production because of active product markets in rural areas.

Uganda is a signatory to various United Nations conventions to eliminate child labour. The Government has designed several institutions and policies to reduce the phenomenon. Provisions were made in the Employment Decree of 1975, the 1995 Constitution, and the Children's Statute of 1996, prohibiting child labour. The task of eliminating child labour has been placed under the mandate of the Child Labour Unit of the Ministry of Gender, Labour and Social Development. Within the policy framework, children are allowed to perform certain duties at home as they progress to adulthood. Light work such as cooking, fetching firewood, fetching water are permitted for children if these tasks are in line with their capacity, and do not pose a threat to their health or interfere with their right to education. Following the ILO definition of child labour, the government prohibits all economic tasks for children below 11 years, while these are acceptable for older children as long as they are not exploitative, hazardous and fall in line with the recommended hours for children in certain age categories. 


\section{Rural markets in Uganda}

Product markets in rural areas exist in different categories. One category comprises of markets that operate on a daily basis. These are usually very small and sparsely distributed outlets that sell a limited assortment of household items. Closely related to these, Nkonya (2002) identified primary fixed traders, who operate in fixed business locations that act as drop-off points for suppliers and pick-up points for customers from mostly urban locations. These may at times travel to producers to make purchases. Nkonya also identified primary non-fixed traders, who do not have permanent business locations, and do not pay trade licenses. Another key category is periodic markets. These operate at specific intervals, such as weekly or monthly. They involve individuals from within the district or from distant locations who purchase or sell agricultural products, inputs, and a variety of household items at a designated location. These markets often operate in the open air or in temporary structures.

Cooperatives were very active before the mid-1990s, and usually involved transactions in crops such as coffee, cotton and tobacco. With liberalisation, they became less competitive and gave way to traders (Fafchamps and Hill, 2005; Hill et al., 2008). The aim of market liberalisation was to encourage the development of the private sector to ease access to agricultural inputs, and encourage better product prices and commercialization. However, this form of market remained operational in the eastern parts of the country where coffee production required such markets. Tobacco growing in western and West Nile parts of the country has also seen the persistence of cooperative market arrangements, where farmers sell output to the company and expect payments at a later date. In recent years, the realization that the private sector was not effective enough to link farmers to markets has encouraged the government to promote village associations and farmers’ groups (Hill et al., 2008).

The above market types differ in the volume and frequency of their transactions. Rural markets that operate daily have a limited volume of transactions compared to periodic markets and cooperatives. While the latter operate during specific agricultural seasons (say harvest time), they are characterized by large transactions at those times. A common feature of rural markets is that they are often associated with high transaction costs (Gollin, and Rogerson, 2010). 


\section{Data description}

The paper uses the Uganda National Household Survey (2005/06). This nationally representative survey was collected by the Uganda Bureau of Statistics between May 2005 and April 2006, using a stratified two-stage sampling design (UBoS, 2006). The first stage involved establishing Enumeration Areas (EA), using the 2002 population and housing census frame. The EAs were delineated based on the population size of each region. The number of EAs in the northern region was doubled to allow for attrition that could result from insecurity. An additional sample of 30 EAs was obtained from the IDP camps to cater for displaced households. The sample size was increased to about 30 EA in 10 districts to have an adequate sample for separate analysis. In all, 783 EAs were selected. The second stage involved obtaining a simple random sample of 10 households in each EA.

The socioeconomic module provides for the types of activities that each individual aged 5 years and above was engaged in during the 7 days preceding the interview, and the number of hours worked in the respective activities ${ }^{4}$. The sample for this analysis is restricted to children aged 5-14 years (10,474 observations in 5,257 households) drawn from the rural population. This age category is selected for comparability with other studies that use an age 14 cut-off (Dehija and Gatti, 2002; Rossati, and Rossi, 2001; Whetten et al., 2011). I dropped the urban sample because child labour has been largely regarded as a rural phenomenon in Uganda (ECLT foundation, 2007; Kyomuhendo et al., 2004; UCW, 2008). Besides, children in the urban sample constitute less than $20 \%$ of all children in the survey.

The community module captures details on the different types of product markets. Three categories of markets are of interest in this paper. One is the limited consumer market, defined in the survey as comprising of a cluster of shops selling a limited number of commodities or services, and often operating on a daily basis. The second type is the periodic local market, held at fixed locations and fixed intervals, where producers, traders,

\footnotetext{
${ }^{4}$ Questions on hours spent in domestic activity include: (a) during the past 7 days how many hours (including travel time) did you spend fetching water for the household? (b) fetching firewood for the household? (c) cooking for the household? (d) taking care of children and the elderly? For economic activity, questions include: During the past 7 days, have you worked: (a) for pay for an enterprise or someone who is not a member of your household at least for one hour in any day? (b) on land owned or occupied by a member of your household either in cultivating crops or in farming tasks, or have you cared for livestock belonging to a member of your household or fishing for at least one hour in any day? (c) on your own account or in a business enterprise belonging to you or someone in your household, for at least one hour in any day? How many hours did you work (in each activity) on each day.
} 
and buyers from the vicinity and from distant places converge and make transactions. Third, is the local cooperative market. This is defined in the survey as consisting of official cooperatives registered under the Cooperative Societies Act. They could also be established informally, consisting of a group of households or individuals that unite to buy or sell outputs and perform related activities jointly.

It would have been worthwhile to investigate how markets would influence both the work and schooling decisions. The challenge is that the data only provide information on whether a child attends school. It is not observable whether the child went to school and the hours of attendance during the week preceding the survey.

\section{Methodology}

I first analyse the effect of proximity to the product market, measured in travel time to the market (Market) on the probability of child labour ( $y_{i}$; domestic activity, economic activity). This is expressed in the probit framework as:

$$
y_{i}^{*}=\beta_{0}+\beta_{1 i} X_{i}+\beta_{2 i} \text { Market }_{i}+u_{i}
$$

Where $y_{i}^{*}$ is a latent variable, such that; $y_{i}=1$ if $y_{i}{ }_{i}>0$ and $y_{i}=0$ if $y_{i}{ }_{i} \leq 0 . X_{i}$ is a vector of child, household, and community-level characteristics. The use of travel time to the market as a proxy is less prone to errors than the estimation of distance. For example, a kilometre traveled from a household located at a hilly terrain may represent significantly greater time costs than the same distance traveled in the plains. The challenge with travel time could be the differences in the means of transport across households. For instance, a household with a vehicle or motor cycle may take less time to reach the market. However this case does not present a substantial challenge given that less than $1 \%$ of the households in the selected sample possess these means of transport.

Normally, households could choose to live in areas where returns are higher, in this case, locations served with markets. This could render the measures of market access susceptible to endogeneity. However, rural households in Uganda are less mobile within their localities. Traditional mechanisms of owning land render relocation less feasible within rural areas. For instance, households tend to live on ancestral land, owned through inheritance or clan system (Doss et al., 2011; Tukahirwa, 2002). About 97.12\% of the sample live on ancestral land. This scenario provides a unique advantage to address the possibility of 
endogeneity of household location decisions. Additionally, controlling for a number of observable household socio-economic controls, and controls for access to other facilities could clear any non-random assignment of households to different travel times to markets. Kondylis and Manacorda (2011) use this approach to study the effect of proximity to school on child labour in Tanzania.

Second, I regress the hours of child work $\left(H_{i}\right.$; total hours, hours in domestic activity, hours in economic activity) on the same set of variables and specifications. Since the OLS model would produce biased and inconsistent estimates due to the presence of zero hours (in this case, 22.3\%), the Tobit model (Tobin, 1958) is preferred. However, in addition to its susceptibility to the violation of the homoscedasticity and normality assumptions, the Tobit model treats all zero values as an outcome of a corner solution. Although some zeros represent a corner solution for children who will never work, this is not applicable for children who would have worked if, for instance, work opportunities existed. In a related strand of the literature (Chiwaula, 2007; Keelan et al., 2008; Sinning, 2007), the doublehurdle model, originally formulated by Cragg (1971) has been estimated as a generalization of the Tobit model. In this framework, observing positive hours of work requires passing two hurdles: first, the participation hurdle (observing positive hours), then the work intensity hurdle (hours of child work). The first stage is modeled as:

$W_{i}^{*}=Z_{i} \alpha+v_{i}$

Where $W_{i}^{*}$ is a the latent describing the decision to participate, such that $W=1$ if $H_{i}>0$ and $W=0$ if $H_{i} \leq 0 . Z_{i}$ is a vector of explanatory variables, $\alpha$ is a vector of parameters, and $v_{i}$ is the error term assumed to be normally distributed. In the second stage, the following model of work intensity is estimated:

$$
H^{*}=\beta_{0}+\beta_{1 i} X_{i}+\beta_{2 i} \text { Market }_{i}+\varepsilon_{i}
$$

Where $H_{i}=0$ if $H_{i}^{*} \leq 0$, and $H_{i}=H_{i}^{*}$ if $H_{i}^{*}>0 . \mathrm{X}$ is a vector of explanatory variables. The error term $\left(\varepsilon_{i}\right)$ follows a bivariate normal distribution. Note that $v_{i}$ and $\varepsilon_{i}$ are assumed to be independent, leading to an independent double-hurdle model. Unlike other two-step models, which often require exclusion restrictions, the presence of a continuous dependent 
variable in this type of model renders exclusion restrictions irrelevant (Blundell and Meghir, 1987).

Because normality is assumed for such models, an inverse hyperbolic sin (IHS) transformation of $H_{i}$ is often applied (Chiwaula, 2010; Keelan et al., 2008; Sinning, 2007). This is continuously defined over positive, zero and negative values. This transformation is defined by:

$$
T\left(H_{i}\right)=\log \left(\gamma H_{i}+\left(\gamma^{2} H_{i}^{2}+1\right)^{1 / 2} / \gamma\right.
$$

Where $\gamma$ is an additional parameter that controls for kurtosis. The variance of $\varepsilon_{i}$ is assumed to vary across observations, in order to take heteroscedasticity into account.

\subsection{Variables}

Two variables are included to reflect child work. In the first category are dummy variables indicating whether one is a child labourer. Given that combining both domestic and economic activity is methodologically challenging (see section 5.2), I analyse these activities separately. One variable is a dummy for child labour in economic activity, reflecting the ILO definition, described in section $5.2^{5}$. Another variable is a dummy for the 28-hour threshold in domestic activity, such that, a child is a labourer if it is aged 5-14 and worked for at least 28 hours of domestic work. I do not explore the debate regarding the validity of work thresholds, but use the thresholds as institutionally defined. The second category includes three continuous variables for hours of child work. These are total hours, hours in domestic activity, and hours in economic activity. Here, I do not consider the thresholds above. Instead, I focus on the intensity of child work in respective activities. Three variables are included to proxy access to product markets. These are; travel time (in minutes) to the nearest limited consumer market, periodic local market, and to the local cooperative market. The data only provide for travel times from the village centre, not from each household in the village. Analysis therefore cannot capture the variation in market access across households in each village. Nonetheless, this shortcoming may not be substantial, given that villages tend to be small in geographic coverage.

\footnotetext{
${ }^{5}$ Refer to footnote 3 for tasks entailed in this categorization.
} 
To ensure that the market access indicator represents physical markets as much as possible, I control for other community level variables that might confound the effect of product markets. These include population density, distance to the nearest town $(\mathrm{Km})$, travel time to the nearest all-weather road (in hours), and whether a primary school is present in the village. I also consider district fixed effects, as well as the month of the interview, to control for seasonality in child work.

I also include a number of controls used in most literature on child labour. The child's age, gender and whether the mother lives in the household are used to control for child characteristics. Dependency ratio, and the age and gender of the head of the household are included to control for household demographic characteristics. To avoid endogeneity, I do not directly control for income because the survey does not explicitly distinguish household earnings that are independent of children's contribution. Instead, household income is proxied by a set of variables. In particular, I include the number of members having higher education (above secondary schooling), and the proportion of adult male and female wage earners. I control for the value of household assets, including land. A dummy for ownership of a non-farm enterprise by at least one member of the household, and that for participation in agricultural activities for the household are constructed to reflect activity status.

\section{Results}

\subsection{Descriptive evidence}

The descriptive statistics in table 1 show that overall, more children were involved in economic activity (e.g. working on the farm, in the household's business or market activities outside the household) than in domestic work (such as childcare, fetching water, fetching fuel wood for the household). In domestic work, the difference between these activities is highly marked, with girls bearing the largest burden (16\% as opposed to $9.5 \%$ for boys), while the proportion of boys is higher than of girls in economic activity (25\% compared to $21 \%$ for girls). This pattern is evident across all ages (figure 1). The gap in domestic work between boys and girls widens with age (figure 2). The burden borne by girls in domestic work is also reflected in hours of work (table 2). While boys on average work 2 hours more than girls in economic activities, girls work 3 hours more in domestic work. Considering the total hours worked, girls on average work for 13 hours a week while boys spend 10 hours; and the gap increases with age (figure 3). 
Although boys work more than girls in economic activity, for almost all ages, the difference is smaller than that between boys and girls in domestic work (Results not included), indicating that the burden of work is placed more on girls on average. Note that the reliability of responses to questions on domestic work depends on how well they were administered. Although the questionnaire explicitly defines the activities for domestic work, bias could arise if some of the resources extracted were used for the production of goods.

The average age of the children in the sample is 9 years. This age corresponds to the third year of primary schooling in Uganda. About 25\% of the children live in households headed by women. This average is consistent across gender and location, although it is higher by $1 \%$ for the girls' sample. About $14 \%$ of the children reside in households with at least one member owning a non-agricultural enterprise. However, the farming sector remains substantially significant, with almost $67 \%$ of the children living in a household with at least one member engaged in farming.

Regarding market access, limited consumer markets are closer than other markets. The average travel time to this type of market is 1 hour, compared to 2.5 hours for periodic local markets, and four hours for local cooperatives. Except for travel time to cooperatives, most children engaged in economic activity, both in terms of thresholds of work and intensity were located close to markets (results not included). On the contrary, children residing further away from markets seemed to work in domestic activity, and this proportion is higher for girls.

\subsection{Empirical results}

\subsubsection{The incidence of child labour}

Tables 3-6 present probit estimates for the incidence of child labour. I focus on specification (iv) where all markets are included. Regarding participation in domestic activity, an increase in the travel time to the nearest limited consumer market increases the incidence of child labour for all children in the sample (table 3). However, when the samples for boys and girls are analysed separately, this effect remains positive and significant only for girls (table 4). This type of market seems to matter more for boys with regard to economic activity (table 5). The further away the household is located from the market, the less likely the boys will be in child labour, with regard to economic activity. The effect on girls in economic activity is marginally significant and negative. 
Travel time to periodic markets appears to influence child labour strongly. Distant periodic markets result in increase in the likelihood of child labour in domestic activity in both, the full sample and the separate models for boys and girls. The corresponding marginal effects for boys and girls, respectively, are 0.04 and 2.7, for each extra hour traveled to the market. Results also indicate a decline in the probability of both boys and girls engaging in economic work, with marginal effects of 0.06 and 0.05 , respectively. A larger marginal effect for boys may reflect their stronger participation than girls in these activities. Distant markets may increase the disincentive to engage in economic activity, thus making it less viable to involve children in this type of work. This may induce households to switch child labour from economic activity, to domestic tasks. This finding supports the literature that argues that households in locations remote from markets may be grounded in subsistence production. Access to local cooperative markets does not appear to significantly affect child labour in either form of activity.

The preceding results apply to all children in the sample across the age groups. However, it is likely that markets can affect children differently, depending on their age. To elucidate the age dimension, table 6 provides results for each age. The specification for cooperative markets is excluded since they were insignificant in the regressions. The results indicate that the effect of limited consumer and periodic markets on domestic work starts taking effect at the age of 12 for boys, while the effect on girls means that they become engaged in labour as early as age 6. This further confirms a gender bias in domestic work. The effect on child labour in economic activity is significant for boys from the ages of 13 and 11 for limited consumer and periodic markets, respectively. This may reflect the possibility that economic work is more demanding in terms of physical effort.

Other characteristics also showed up significantly. The incidence of child labour in both categories of work increases significantly with child age. The presence of the mother strongly reduces the likelihood of child labour in domestic activity. There is evidence in the literature that mothers are altruistic towards their children (Liu et al., 2000). It is likely that they would be more likely to postpone activities that would jeopardise child welfare. The probability of child labour in both domestic and economic activity increases for children residing in households with a high dependency ratio (table 4). In the separate models, dependency ratio only increases the participation of girls in domestic work. A higher number of dependents could increase the demand for childcare time within the household, as well as for replacement of the elderly (above 64 years) in economic activity, thereby demanding more of girls' time 
in domestic work. On the other hand, boys work more in economic activity. The incidence of child labour in domestic activity is low for children living in households with older heads. However, the effect of head age is stronger for economic activity.

Proxies for household income and human capital exhibit varied effects on child labour. A larger proportion of members with an education level above secondary is strongly associated with a decrease in the incidence of child labour, specifically for girls in domestic activity. The decline in the incidence of child labour in this category is plausible, given that adult education may increase employment prospects and postpone child involvement in detrimental work.

Unsurprisingly, the incidence of child labour in economic activity is stronger if children live in households that engage in farming activity. Among the community-level variables, population density and travel time to the nearest all-weather road and distance appear to strongly influence child labour in the full sample (table 3). These variables are associated with an increase in child labour in domestic work. A large population may increase demand for products, thereby inducing households to highly value child time in production.

\subsubsection{Hours of child work}

Results for child hours of work are presented for total hours of work, hours of domestic work, and hours of economic work. For all specifications, the Likelihood Ratio tests (table 7) reject the null hypotheses that the Tobit model is correctly specified, suggesting that the independent double-hurdle model is a better representation of the data generating process. Therefore, in what follows, I focus my results on the double-hurdle model.

Results for the full sample (table 8) show that distance to the markets has a strong effect on the supply of child labour. The effect of the limited consumer market and the periodic market is significantly positive for total hours worked and time spent in domestic activity, while cooperative markets remain insignificant across specifications. The results for total time worked for the separate samples of boys and girls (table 9) and time in domestic activity (table 10) remained largely consistent with both the full sample and probit estimates. Like in the probit model, the relationship with economic activity is also negative (table 11).

Periodic markets also turned out significant. An increase in the travel time to the market is associated with an increase in total hours of child work and the hours in domestic work. However, children work less in economic activity when these markets are distant. It 
appears that the increase in the hours of child work is largely ascribable to domestic activity, such that the decline in economic activity may not be sufficient to counter an increase in total hours of work. The variable for cooperative markets turned out insignificant.

Results for different age categories (table 12) show that the total intensity of work for boys increases with the travel time to limited consumer market, starting at age 13 . However, for domestic activity, markets are significant for boys starting as early as 9 years of age. For girls, the results show that travel time to consumer markets has a significant effect for domestic work, even when the children are younger. Disaggregation for local periodic markets also reveals significant results for older children. Thus, while isolation from markets increases time in domestic work for boys when they are still young, they enter the child labour category at a later age, contrary to girls who work more intensely quite early.

\subsection{Robustness checks}

As a robustness check, I use self-reported distance (in Km) to the market (tables 13 and 14). In spite of the susceptibility of this measure to measurement error, the findings turned out to be largely consistent with travel time, except for the probit model of domestic activity.

In tables 15 and 16, I proxy market access with actual physical location of the market. In this case, I construct three dummy variables indicating whether the market is positioned; in the village or in the nearby village, at the nearest trading center, or at the district town or beyond. The results appeared to be consistent only for the periodic market. While this approach could in some way reflect proximity to markets, results cannot be relied upon because the measure is less definite. For instance, a market located close to the nearest trading center can be distant for households in certain villages. The trading center might also be located in the same village.

\section{Conclusions}

This paper analyses how access to markets affects the incidence of child labour and the intensity of child work. The major contribution to the child labour literature is that I empirically study how different types of product markets relate to the intensity of child involvement in domestic and economic activity.

Using data from rural Uganda, collected in 2005, and focusing on children aged 5-14, I find that, the intensity of child work increases when households are distant, either from small 
but more frequent markets or periodic markets that sell a wide range of products. This intensity of work seems to be driven mostly by an increase in domestic activity, when travel time to these markets increases. Consistent with work intensity, longer travel time to the market acts to increase the likelihood of child labour in domestic activity, almost across gender, while child labour in economic work declines. Girls are also observed to work at an earlier age than boys.

One key lesson that shows up in the data is that, when households are exposed to market opportunities, they can be induced to utilize the available resources, one of which is children. When households are isolated, child time is instead switched from economic to domestic production. These results underscore the need to design interventions that enable households to benefit from product market expansion, without exploiting children. Interventions could put attention to incentives that aim to reduce the value of child time at work, in favour of other developmental activities such as schooling. 


\section{References.}

Afeikhena J. and O. Ogunkola, 2000. Characteristics and behaviour of African commodity/product markets and market institutions and their consequences for economic Growth, CID Working Paper No. 35.

Bagamba, F., 2007. Market access and agricultural production: The case of banana production in Uganda, PhD Thesis, Wageningen University.

Barrett, C.B., T. Reardon and P. Webb, 2001. Nonfarm income diversification and household livelihood strategies in rural Africa: Concepts, Dynamics, and Policy Implications, Food Policy 26 (4), pp. 315-331.

Basu K. and P.H. Van, 1998. The economics of child labour, American Economic Review 88 (3), pp. 412-427.

Betcherman, G. J. Fares, A. Luinstra and R. Prouty, 2004. Child labour, education and children's rights, World Bank Social Protection Discussion Paper Series No. 0412. World Bank, Washington, DC.

Blundell, R.W. and C. Meghir, 1987. Bivariate alternatives to the Univariate Tobit Model, Journal of Econometrics 34, pp. 179-200.

Burbidge, J. B., L. Magee, and A.L. Robb, 1988. Alternative transformations to handle extreme values of the dependent variable, Journal of the American Statistical Association 83, pp. 123-127.

Chiwaula, L.S., 2010. Household poverty and child labour decisions in Malawi, in Randall K.Q. Akee, Eric V. Edmonds, Konstantinos Tatsiramos (eds.) Child Labour and the transition between school and work, Research in Labour Economics, Volume 31, Emerald Group Publishing Limited, pp.33-51.

Cigno, A., Rosati, F.C. and L. Guarcello, 2002. Does globalization increase child labour? World Development 30, pp. 1579-1589.

Dehejia R. H. and R. Gatti, 2002. Child labour: The role of income variability and access to credit across countries, NBER Working Paper No. 9018.

Dercon, S. and J. Hoddinott, 2005. Livelihoods, growth, and links to market towns in 15 Ethiopian villages. International Food Policy Research Institute, FCND Discussion Paper No. 194.

Doss, C., M. Truong, G. Nabanoga and J. Namaalwa, 2011. Women, marriage and asset inheritance in Uganda, Chronic Poverty Research Center, Working Paper No. 184.

Edmonds, Eric V. and N. Pavcnik, 2005. Child labour in the global economy, Journal of Economic Perspectives 19, pp.199-220.

Eff, E. A. and C.D. Jensen, 2007. The integration of periodic markets in Mayan Guatemala: A gravity approach, Department of Economics and Finance Working Paper Series, April, 2007.

Fafchamps, M. and S. Forhad, 2003. The spatial division of labour in Nepal, Journal of Development Studies 39 (6), pp. 23-66.

Fafchamps, M. and F. Shilpi, 2003. The Spatial division of labour in Nepal, Journal of Development Studies 39(6), pp. 23-66. 
Fafchamps, M. and F. Shilpi., 2005. Cities and specialization: Evidence from South Asia, .Economic Journal 115, pp. 477-504.

Fafchamps, $M$ and J. Wahba, 2006. Child labour, urban proximity, and household composition, Journal of Development Economics 79, pp. 374- 397.

Fafchamps, M. and R.V. Hill, 2005. Price transmission and trader entry in domestic commodity markets, Global Poverty Research Group, Working Paper Series No. 038.

Fally, T, R. Paillacar and C. Terra, 2010. Economic geography and wages in Brazil: Evidence from micro-data, Journal of Development Economics 91, pp. 155-168.

Fishe, R. P. H., G. S. Maddala, and R. P. Trost, 1979. "Estimation of a heteroscedastic Tobit model." University of Florida.

Gibbons, E.D., F. Huebler and E. Loaiza, 2005. Child labour, education and the principle of non-discrimination. UNICEF, Division of Policy and Planning. UNICEF Staff Working Paper, November, 2005.

Gollin, D. and R. Rogerson, 2010. Agriculture, roads, and economic development in Uganda, NBER Working Paper No. 15863.

Grossmann, H. and J. Michaelis, 2007. Trade sanctions and the incidence of child labor, Review of Development Economics, 11(1), pp. 49- 62.

Gustafsson-Wright, E. and H.H. Pyne, 2002. Gender dimensions of child labour and street children in Brazil, World Bank, Policy Research Working Paper No. 2897.

Guarcello, L. and S. Lyon, 2004. Child labour in Bolivia: A comparison of estimates from MECOVI and MICS survey instruments, Understanding Children's Work Project Working Paper, January, 2004.

Guarcello, L., Lyon, S. and F. Rossati, 2004. Child labour and access to basic services: evidence from five countries, Understanding Children's Work Project Working Paper, January, 2004.

Hazarika G. and S. Sarangi, 2008. Household access to microcredit and child work in rural Malawi, World Development 36 (5), pp.843-859.

Hill, R.V., T. Bernard, and R. Dewina, 2008. Cooperative behaviour in rural Uganda: Evidence from the Uganda National Household Survey 2005, Uganda Strategy Support Programme, Background Paper No. USSP02.

Hou, Z., 2011. Channels through which market access affects income: Farm vs. non-farm activities in rural China, National University of Singapore, Mimeo.

Ilahi, N, F. Peter and S. Guilherme, 2001. The implications of child labour for adult wages, income and poverty: Retrospective evidence from Brazil, Mimeo.

International Labour Organisation, 1973. Convention concerning minimum age for admission to employment, International Labour Office, Geneva Child Labour, 58th Sess. (1973).

International Labour Organisation, 1999. Convention concerning the prohibition and immediate action for the elimination of the worst forms of child labour, International Labour Office, Geneva. 87th Sess. (1999)

International Labour Organisation, 2007. Uganda: Decent Work Country Programme. ILO Office for the United Republic of Tanzania, Kenya, Somalia and Uganda, 2007-2010.

International Program for Elimination of Child labour, 2001. Child labour in Uganda. A report based on the 2000/2001 Uganda Demographic and Health Survey, ILO, Geneva. 
International Program for Elimination of Child labour, 2002. Every child counts: New global estimates on child labour. ILO, Geneva.

International Program for Elimination of Child labour, 2012. Tracking child labour: From commitment to action, ILO, Geneva.

Jafarey, S. and S. Lahiri, 2002. Will trade sanctions reduce child labour? The role of credit markets, Journal of Development Economics 68 (1), pp. 137 - 156.

Keelan, C., Newman, C., and M. Henchion, 2008. Quick-service expenditure in Ireland: Parametric vs. nonparametric analysis, Journal of Applied Economics 40, pp. 26592669.

Kyomuhendo, S., R. Ssenabulya and M. Matovu, 2004. The nature, prevalence and other dynamics of child labour within the coffee agricultural sector in Uganda: Employers' perspective, Federation of Uganda Employers, Rapid Assessment report, August, 2004.

Kondylis, F. and M. Manacorda, 2011. School proximity and child labour evidence from rural Tanzania, Journal of Human Resources 47 (1), pp. 32 - 63.

Kruger, D.I., 2007. Coffee production effects on child labour and schooling in rural Brazil, Journal of Development Economics, 82 (2), pp. 448 - 463.

Leinyuy, J., 2008. The impact of business opportunities on child labour and schooling in an economy with incomplete labour market, Toulouse School of Economics, Mimeo.

Liu, J., J. K. Hammitt, J. Wang and J. Liu, 2000. Mother's willingness to pay for her own and her child's health: A contingent valuation study in Taiwan, Health Econ. 9, pp. 319-326

Loury, G. 1981. Intergenerational transfers and the distribution of earnings, Econometrica 49, pp. 843- 67.

Lyon, S and C. Valdivia, 2010. Toward the effective measurement of child domestic workers: Building estimates using standard household survey instruments, Understanding Child Work project, ILO, Geneva.

Minten B., 1999. Infrastructure, market access, and agricultural prices: Evidence from Madagascar, MSSD Discussion paper No. 26.

Nkonya, F., 2002. Uganda crop market characteristics, constraints and opportunities, International Food Policy Research Institute, Mimeo.

Nugent, J.B. 1985. The old-age security motive for fertility, Population and Development Review 11 (1), pp. 75-97.

Pouliot, W., 2006. Introducing uncertainty in Baland and Robinson's model of child Labour. Journal of Development Economics 79, pp. 264-72.

Ranjan, P., 2001. Credit constraints and the phenomenon of child labour, Journal of Development Economics 64, pp. 81-102.

Redding S. and A.J. Venables, 2004, Economic geography and international inequality, Journal of International Economics 62(1), pp. 53-82.

Rosenzweig, M. R. and R. Evenson, 1977. Fertility, schooling, and the economic contribution of children in rural India: An econometric analysis, Econometrica 45(5), pp. 10651078.

Rossati, F. and M. Rossi, 2001. Child labour and human capital accumulation: Evidence from Pakistan and Nicaragua, Understanding Children's Work Research Paper, October 2001. 
Rossati, F.C. and M. Rossi, 2007. Impact of school quality on child labour and school attendance: The case of the CONAFE compensatory education programme in Mexico, Understanding Children's Work Project, February, 2007.

Sinning, M., 2007. Determinants of savings and remittances: Empirical evidence from immigrants to Germany, IZA Discussion Paper No. 2966, 32.

Ssewanyana, S.N, 2009. Chronic poverty and household dynamics in Uganda, Chronic Poverty Research Centre, Working Paper No. 139.

Tobin, J., 1958. Estimation of relationships for limited dependent variables, Econometrica 26, pp. 24 - 36.

Tukahiirwa, J.M.B., 2002. Policies, people and land use change in Uganda. A case study in Ntungamo, Lake Mburo and Sango Bay sites, International Livestock Research Insitute, Nairobi, Kenya.

Udosen, C. and D. Adams, 2009. A spatio-temporal synchronization of periodic markets: evidence from the hinterland of Akwa Ibom state, Journal of Social Sciences 8(1), pp. 27-37.

Uganda Bureau of Statistics, 2003.Uganda National Household Survey 2002/2003, Report on the labour force survey. Uganda Bureau of Statistics, Kampala.

Understanding Children's Work, 2008. Understanding children's work in Uganda. International Labour Office, Report on child labour, August 2008.

Understanding Children's Work, 2010. Joining forces against child labour. Inter-agency report for the Hague Global Child Labour Conference of 2010, Understanding Children’s Work Programme, May, 2010.

UNCTAD, 2008. Organic agriculture and food security in Africa, UNEP-UNCTAD Capacity-building Task Force on Trade, Environment and Development, United Nations, New York and Geneva.

Whetten, R,. L. Messer, J. Ostermann, K.Whetten, B.W. Pence, M. Buckner, N. Thielman, and K. O’Donnell, 2011. Child work and labour among orphaned and abandoned children in five low and middle income countries, BMC International Health and Human Rights 2011.

Wolpin, K. I. 1984. An estimable dynamic stochastic model of fertility and child mortality, Journal of Political Economy 22 (5), pp. 852- 874.

Yao, X., 2003. Infrastructure and poverty reduction-making markets work for the poor, ERD policy brief, Series No. 14. 


\section{Appendix}

Figure 1. Proportion of child labourers in economic work

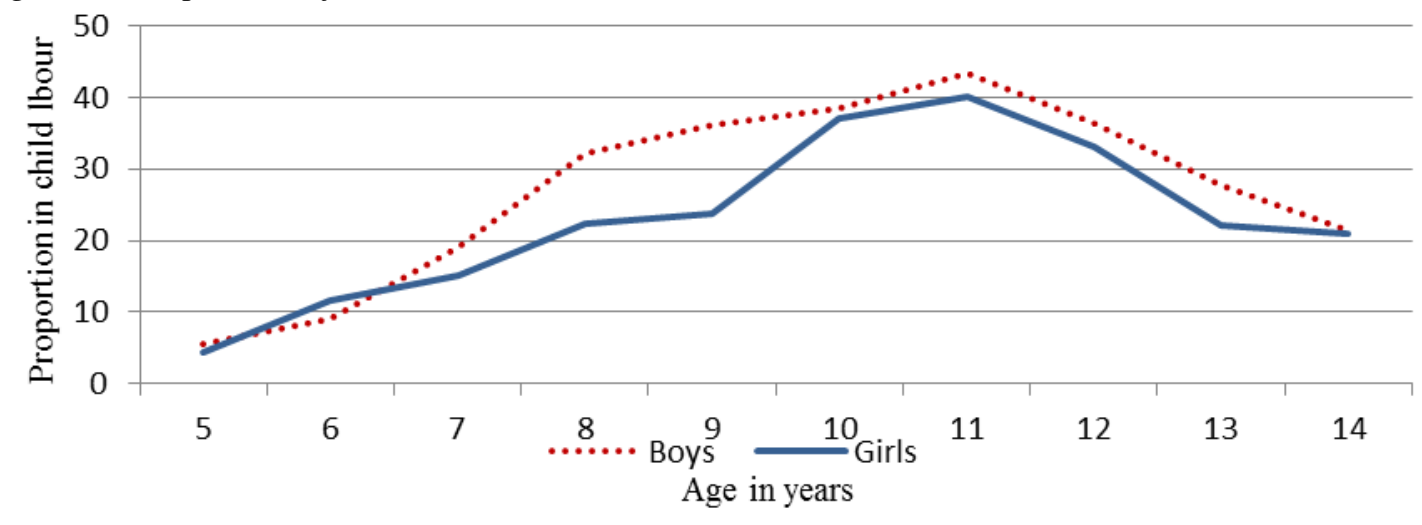

Figure 2. Proportion of child labourers in domestic work

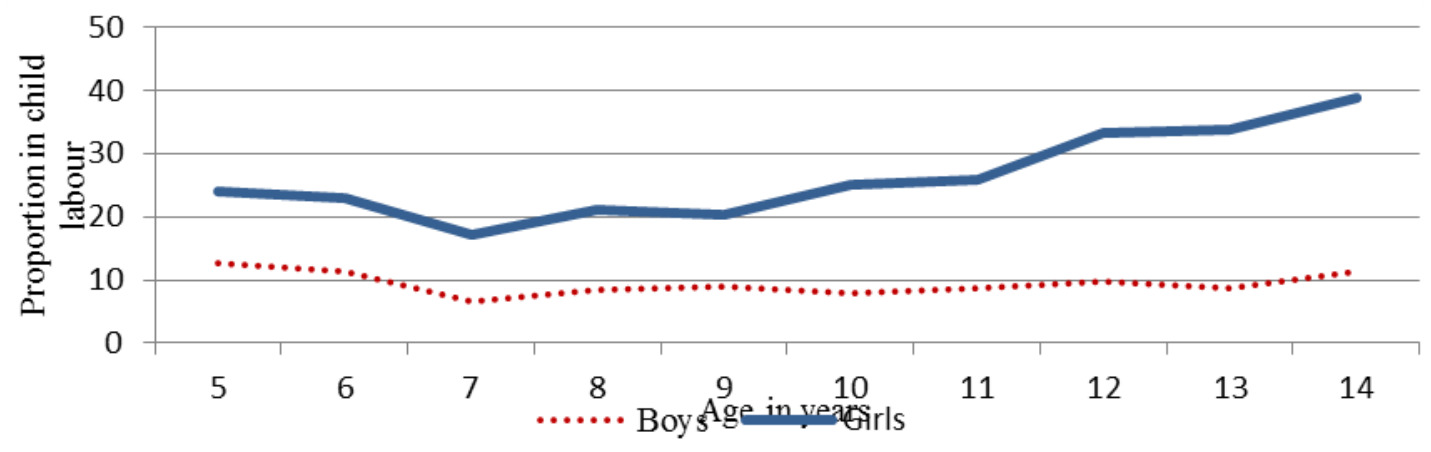

Figure 3. Total hours of child work

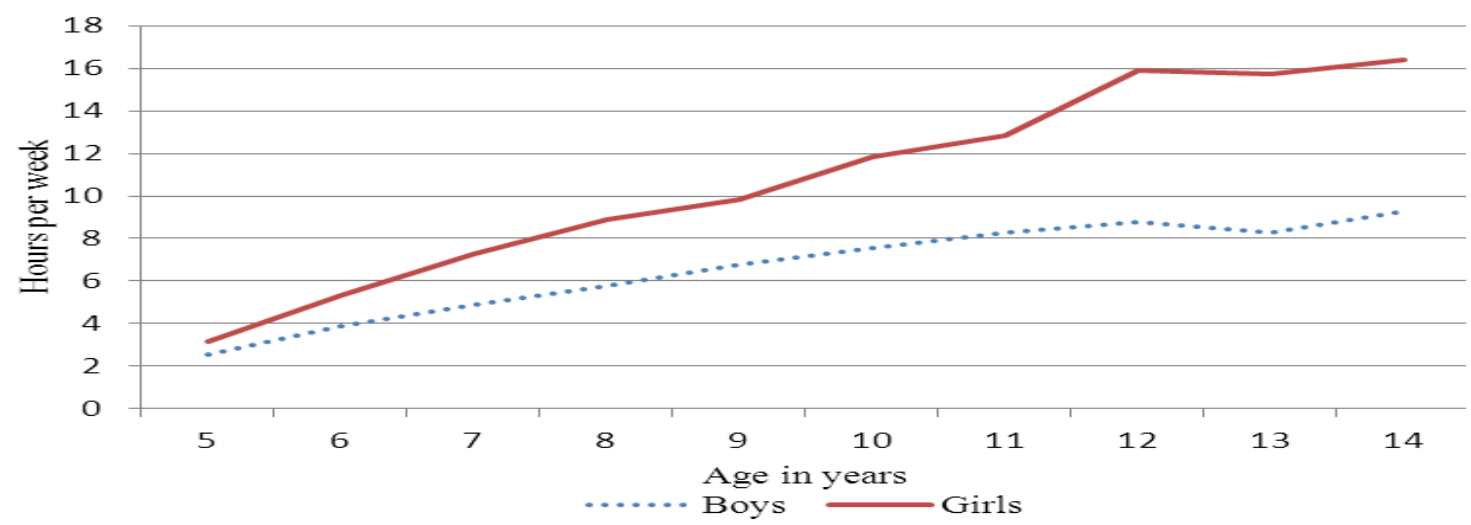




\begin{tabular}{lcc}
\hline & & \\
& Domestic activity & Economic activity \\
\cline { 2 - 3 } & $\%$ & $\%$ \\
\hline Boys & 9.48 & 24.65 \\
Girls & 16.40 & 21.26 \\
All & 12.93 & 22.96 \\
\hline
\end{tabular}

Note: statistics based on rural children aged 5-14. Household weights were used.

Table 2. Descriptive statistics

\begin{tabular}{|c|c|c|c|c|c|c|c|}
\hline \multirow[t]{2}{*}{ Variable } & \multicolumn{2}{|c|}{ All } & \multicolumn{2}{|c|}{ Boys } & \multicolumn{2}{|c|}{ Girls } & \multirow{2}{*}{$\begin{array}{l}\text { Mean diff. } \\
(P \text {-value })\end{array}$} \\
\hline & Mean & S.D & Mean & $S . D$ & Mean & S.D & \\
\hline \multicolumn{8}{|l|}{ CHILD CHARACTERISTICS } \\
\hline Child's age & 9.29 & 2.88 & 9.30 & 2.88 & 9.27 & 2.89 & 0.689 \\
\hline Child is female (Yes $=1, \mathrm{No}=0$ ) & 0.50 & 0.50 & & & & & \\
\hline Mother in the house (Yes=1, No=0) & 0.70 & 0.46 & 0.71 & 0.45 & 0.69 & 0.46 & 0.146 \\
\hline \multicolumn{8}{|l|}{ HOUSEHOLD CHARACTERISTICS } \\
\hline Dependency ratio $^{6}$ & 0.60 & 0.15 & 0.60 & 0.15 & 0.60 & 0.15 & 0.449 \\
\hline Age of the head in years & 44.86 & 13.59 & 45.26 & 13.63 & 44.46 & 13.54 & 0.043 \\
\hline Head is female $((\mathrm{Yes}=1, \mathrm{No}=0)$ & 0.25 & 0.44 & 0.25 & 0.43 & 0.26 & 0.44 & 0.072 \\
\hline $\begin{array}{l}\text { Prop. adults with } \\
\text { schooling>secondary }\end{array}$ & 0.17 & 0.52 & 0.17 & 0.51 & 0.17 & 0.52 & 0.392 \\
\hline $\begin{array}{l}\text { Hh involved in farming (Yes=1, } \\
\text { No=0) }\end{array}$ & 0.67 & 0.47 & 0.67 & 0.47 & 0.67 & 0.47 & 0.517 \\
\hline $\begin{array}{l}\text { Hh has non-farm enterprise (Yes=1, } \\
\text { No=0) }\end{array}$ & 0.14 & 0.35 & 0.14 & 0.35 & 0.14 & 0.34 & 0.989 \\
\hline Prop. of adult female wage earners & 0.06 & 0.26 & 0.05 & 0.25 & 0.06 & 0.27 & 0.077 \\
\hline Prop. of adult male wage earners & 0.16 & 0.42 & 0.15 & 0.40 & 0.17 & 0.44 & 0.005 \\
\hline Total value of assets (000 Ug. Shs) & 7375 & 31600 & 6882 & 30100 & 6868 & 31100 & 0.529 \\
\hline $\begin{array}{l}\text { COMMUNITY-LEVEL CHARACTERIST } \\
\text { Primary school in the village (Yes=1, } \\
\text { No=0) }\end{array}$ & 0.37 & 0.49 & 0.39 & 0.49 & 0.41 & 0.49 & 0.113 \\
\hline Population density & $\begin{array}{l}370.7 \\
1\end{array}$ & $\begin{array}{l}509.3 \\
0\end{array}$ & $\begin{array}{l}362.6 \\
8\end{array}$ & $\begin{array}{l}470.3 \\
9\end{array}$ & 378.81 & 545.62 & 0.234 \\
\hline Distance to town (km) & 2.04 & 0.03 & 2.04 & 0.04 & 2.04 & 0.04 & 0.797 \\
\hline $\begin{array}{l}\text { Tr. Time to all-weather road } \\
\text { (minutes) }\end{array}$ & 7.45 & 0.21 & 7.45 & 0.21 & 7.45 & 0.21 & 0.893 \\
\hline $\begin{array}{l}\text { HOURS OF CHILD WORK } \\
\text { Total hours of child work }\end{array}$ & 11.84 & 13.49 & 10.41 & 12.64 & 13.27 & 14.15 & 0.031 \\
\hline Hours in domestic work & 8.46 & 10.20 & 6.51 & 8.30 & 10.44 & 11.47 & 0.004 \\
\hline Hours in economic work & 10.92 & 11.67 & 11.88 & 13.07 & 9.84 & 9.73 & 0.000 \\
\hline \multicolumn{8}{|l|}{ TRAVEL TIMES TO MARKETS } \\
\hline $\begin{array}{l}\text { Most limited consumer market } \\
\text { (hours) }\end{array}$ & 1.24 & 0.17 & 1.24 & 0.17 & 1.23 & 0.16 & 0.148 \\
\hline Most periodic local market (hours) & 2.49 & 0.64 & 2.48 & 0.64 & 2.49 & 0.64 & 0.721 \\
\hline Local cooperative market (hours) & 4.14 & 0.91 & 4.14 & 0.91 & 4.14 & 0.92 & 0.329 \\
\hline
\end{tabular}

${ }^{6}$ Proportion of individuals aged below 18 and above 64 years in the household. 
Note: Statistics based on rural children aged 5-14

Table 3. Probit regression for all children (Marginal effects)

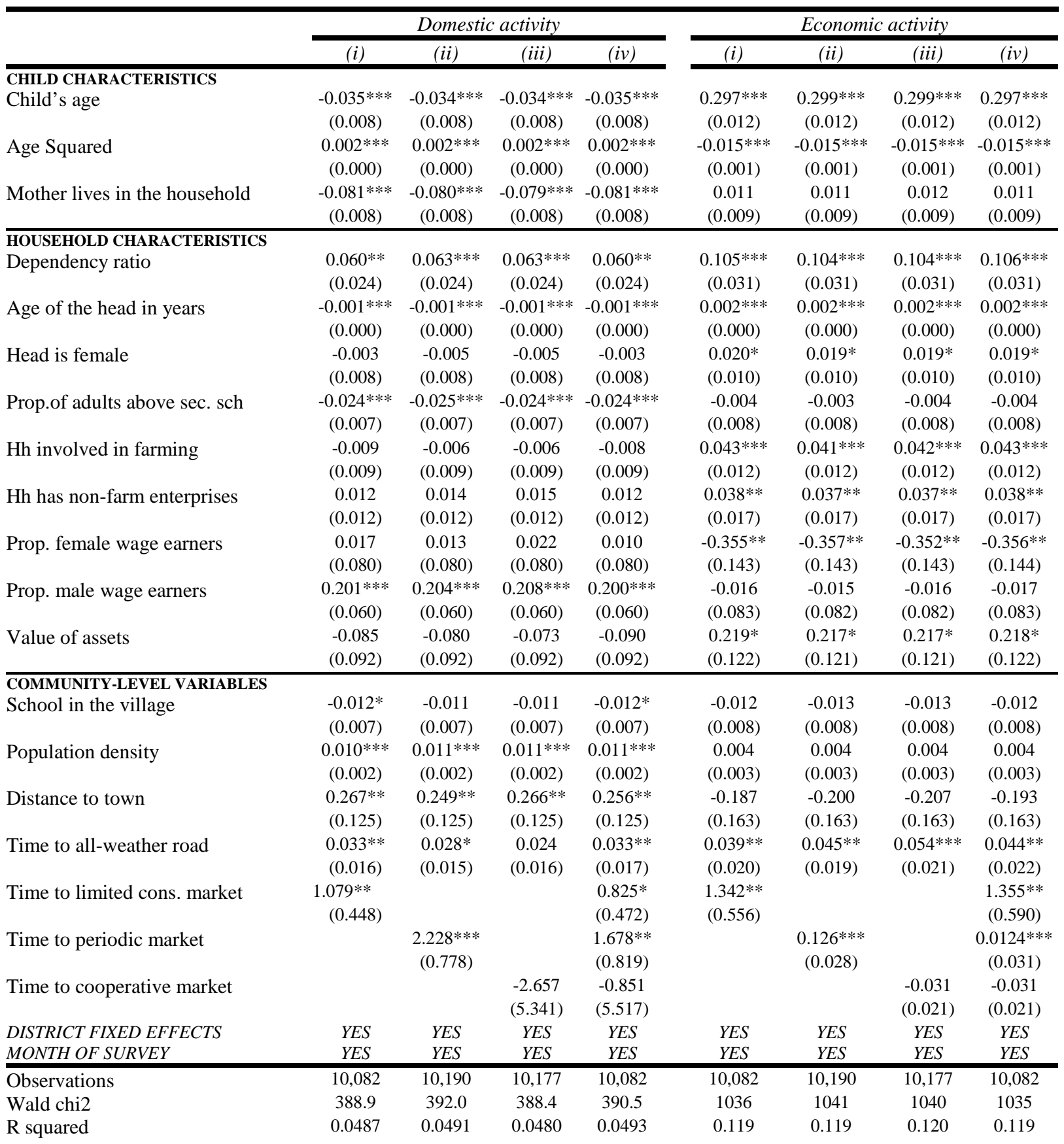


Table 4. Probit regression for domestic activity (Marginal effects)

\begin{tabular}{|c|c|c|c|c|c|c|c|c|}
\hline & \multicolumn{4}{|c|}{ Boys } & \multicolumn{4}{|c|}{ Girls } \\
\hline & (i) & (ii) & (iii) & (iv) & (i) & (ii) & (iii) & (iv) \\
\hline \multicolumn{9}{|l|}{ CHILD CHARACTERISTICS } \\
\hline Child's age & $\begin{array}{c}-0.035^{* * *} \\
(0.010)\end{array}$ & $\begin{array}{c}-0.035^{* * *} \\
(0.010)\end{array}$ & $\begin{array}{c}-0.035^{* * *} \\
(0.010)\end{array}$ & $\begin{array}{c}-0.035^{* * *} \\
(0.010)\end{array}$ & $\begin{array}{c}-0.036^{* * *} \\
(0.013)\end{array}$ & $\begin{array}{c}-0.033 * * \\
(0.013)\end{array}$ & $\begin{array}{c}-0.034^{* * *} \\
(0.013)\end{array}$ & $\begin{array}{c}-0.036 * * * \\
(0.013)\end{array}$ \\
\hline Age Squared & $\begin{array}{c}0.002 * * * \\
(0.001)\end{array}$ & $\begin{array}{c}0.002^{* * *} \\
(0.001)\end{array}$ & $\begin{array}{c}0.002 * * * \\
(0.001)\end{array}$ & $\begin{array}{c}0.002^{* * *} \\
(0.001)\end{array}$ & $\begin{array}{c}0.003 * * * \\
(0.001)\end{array}$ & $\begin{array}{c}0.003^{* * *} \\
(0.001)\end{array}$ & $\begin{array}{c}0.003^{* * * *} \\
(0.001)\end{array}$ & $\begin{array}{c}0.003^{* * * *} \\
(0.001)\end{array}$ \\
\hline Mother lives in the household & $\begin{array}{c}-0.068^{* * *} \\
(0.011)\end{array}$ & $\begin{array}{c}-0.067 * * * \\
(0.011)\end{array}$ & $\begin{array}{c}-0.068^{* * *} \\
(0.011)\end{array}$ & $\begin{array}{c}-0.068^{* * *} \\
(0.011)\end{array}$ & $\begin{array}{c}-0.090 * * * \\
(0.013)\end{array}$ & $\begin{array}{c}-0.088^{* * * *} \\
(0.013)\end{array}$ & $\begin{array}{c}-0.088^{* * *} \\
(0.013)\end{array}$ & $\begin{array}{c}-0.090^{* * * *} \\
(0.013)\end{array}$ \\
\hline \multicolumn{9}{|c|}{ HOUSEHOLD CHARACTERISTICS } \\
\hline Dependency ratio & $\begin{array}{c}0.030 \\
(0.029)\end{array}$ & $\begin{array}{c}0.036 \\
(0.029)\end{array}$ & $\begin{array}{c}0.036 \\
(0.029)\end{array}$ & $\begin{array}{c}0.031 \\
(0.029)\end{array}$ & $\begin{array}{c}0.081^{* *} \\
(0.039)\end{array}$ & $\begin{array}{c}0.086^{* *} \\
(0.039)\end{array}$ & $\begin{array}{c}0.088^{* *} \\
(0.039)\end{array}$ & $\begin{array}{c}0.082^{* *} \\
(0.039)\end{array}$ \\
\hline Age of the head in years & $\begin{array}{c}-0.001 * * * \\
(0.000)\end{array}$ & $\begin{array}{c}-0.001^{* *} \\
(0.000)\end{array}$ & $\begin{array}{c}-0.001^{* *} \\
(0.000)\end{array}$ & $\begin{array}{c}-0.001 * * * \\
(0.000)\end{array}$ & $\begin{array}{c}-0.001 * * * \\
(0.000)\end{array}$ & $\begin{array}{c}-0.001 * * * * \\
(0.000)\end{array}$ & $\begin{array}{c}-0.001 * * * \\
(0.000)\end{array}$ & $\begin{array}{c}-0.001^{* * * *} \\
(0.000)\end{array}$ \\
\hline Head is female & $\begin{array}{c}0.001 \\
(0.010)\end{array}$ & $\begin{array}{l}-0.000 \\
(0.009)\end{array}$ & $\begin{array}{l}-0.000 \\
(0.009)\end{array}$ & $\begin{array}{c}0.001 \\
(0.010)\end{array}$ & $\begin{array}{l}-0.006 \\
(0.012)\end{array}$ & $\begin{array}{l}-0.010 \\
(0.012)\end{array}$ & $\begin{array}{l}-0.009 \\
(0.012)\end{array}$ & $\begin{array}{l}-0.007 \\
(0.012)\end{array}$ \\
\hline Prop.of adults above sec. sch & $\begin{array}{l}-0.014 \\
(0.009)\end{array}$ & $\begin{array}{l}-0.014 \\
(0.009)\end{array}$ & $\begin{array}{l}-0.014 \\
(0.009)\end{array}$ & $\begin{array}{l}-0.014 \\
(0.009)\end{array}$ & $\begin{array}{c}-0.034^{* * *} \\
(0.011)\end{array}$ & $\begin{array}{c}-0.036 * * * \\
(0.011)\end{array}$ & $\begin{array}{c}-0.035^{* * *} \\
(0.011)\end{array}$ & $\begin{array}{c}-0.035^{* * * *} \\
(0.011)\end{array}$ \\
\hline Hh involved in farming & $\begin{array}{l}-0.008 \\
(0.012)\end{array}$ & $\begin{array}{l}-0.007 \\
(0.012)\end{array}$ & $\begin{array}{l}-0.007 \\
(0.012)\end{array}$ & $\begin{array}{l}-0.008 \\
(0.012)\end{array}$ & $\begin{array}{c}-0.012 \\
(0.015)\end{array}$ & $\begin{array}{l}-0.007 \\
(0.015)\end{array}$ & $\begin{array}{c}-0.008 \\
(0.015)\end{array}$ & $\begin{array}{l}-0.012 \\
(0.015)\end{array}$ \\
\hline Hh has non-farm enterprises & $\begin{array}{c}0.013 \\
(0.015)\end{array}$ & $\begin{array}{c}0.014 \\
(0.015)\end{array}$ & $\begin{array}{c}0.014 \\
(0.015)\end{array}$ & $\begin{array}{c}0.013 \\
(0.015)\end{array}$ & $\begin{array}{c}0.010 \\
(0.019)\end{array}$ & $\begin{array}{c}0.014 \\
(0.020)\end{array}$ & $\begin{array}{c}0.014 \\
(0.020)\end{array}$ & $\begin{array}{c}0.010 \\
(0.019)\end{array}$ \\
\hline Prop. female wage earners & $\begin{array}{l}-0.151 \\
(0.110)\end{array}$ & $\begin{array}{l}-0.148 \\
(0.110)\end{array}$ & $\begin{array}{l}-0.146 \\
(0.110)\end{array}$ & $\begin{array}{l}-0.151 \\
(0.110)\end{array}$ & $\begin{array}{c}0.097 \\
(0.116)\end{array}$ & $\begin{array}{c}0.083 \\
(0.116)\end{array}$ & $\begin{array}{c}0.101 \\
(0.116)\end{array}$ & $\begin{array}{c}0.087 \\
(0.116)\end{array}$ \\
\hline Prop. male wage earners & $\begin{array}{c}0.116 \\
(0.074)\end{array}$ & $\begin{array}{l}0.127^{*} \\
(0.073)\end{array}$ & $\begin{array}{l}0.129^{*} \\
(0.073)\end{array}$ & $\begin{array}{c}0.118 \\
(0.073)\end{array}$ & $\begin{array}{c}0.259 * * * \\
(0.094)\end{array}$ & $\begin{array}{c}0.270 * * * \\
(0.093)\end{array}$ & $\begin{array}{c}0.268 * * * \\
(0.094)\end{array}$ & $\begin{array}{c}0.260 * * * \\
(0.094)\end{array}$ \\
\hline Value of assets & $\begin{array}{c}0.025 \\
(0.115)\end{array}$ & $\begin{array}{c}0.029 \\
(0.116)\end{array}$ & $\begin{array}{c}0.026 \\
(0.116)\end{array}$ & $\begin{array}{c}0.023 \\
(0.115)\end{array}$ & $\begin{array}{l}-0.083 \\
(0.147)\end{array}$ & $\begin{array}{l}-0.078 \\
(0.147)\end{array}$ & $\begin{array}{l}-0.057 \\
(0.147)\end{array}$ & $\begin{array}{l}-0.089 \\
(0.147)\end{array}$ \\
\hline COMMUNITY-LEVEL VARIA & & & & & & & & \\
\hline School in the village & $\begin{array}{c}-0.017 * * \\
(0.008)\end{array}$ & $\begin{array}{c}-0.017 * * \\
(0.008)\end{array}$ & $\begin{array}{c}-0.018^{* *} \\
(0.008)\end{array}$ & $\begin{array}{c}-0.018 * * \\
(0.008)\end{array}$ & $\begin{array}{c}-0.006 \\
(0.011)\end{array}$ & $\begin{array}{l}-0.003 \\
(0.010)\end{array}$ & $\begin{array}{c}-0.002 \\
(0.011)\end{array}$ & $\begin{array}{c}-0.005 \\
(0.011)\end{array}$ \\
\hline Population density & $\begin{array}{c}0.011^{* * *} \\
(0.002)\end{array}$ & $\begin{array}{c}0.010^{* * * *} \\
(0.002)\end{array}$ & $\begin{array}{c}0.010^{* * * *} \\
(0.002)\end{array}$ & $\begin{array}{c}0.010^{* * * *} \\
(0.002)\end{array}$ & $\begin{array}{c}0.012 * * * \\
(0.003)\end{array}$ & $\begin{array}{c}0.014 * * * \\
(0.003)\end{array}$ & $\begin{array}{c}0.013^{* * * *} \\
(0.003)\end{array}$ & $\begin{array}{c}0.013^{* * *} \\
(0.003)\end{array}$ \\
\hline Distance to town & $\begin{array}{c}0.175 \\
(0.153)\end{array}$ & $\begin{array}{c}0.164 \\
(0.153)\end{array}$ & $\begin{array}{c}0.167 \\
(0.153)\end{array}$ & $\begin{array}{c}0.178 \\
(0.153)\end{array}$ & $\begin{array}{c}0.293 \\
(0.199)\end{array}$ & $\begin{array}{c}0.262 \\
(0.198)\end{array}$ & $\begin{array}{c}0.306 \\
(0.199)\end{array}$ & $\begin{array}{c}0.269 \\
(0.198)\end{array}$ \\
\hline Time to all-weather road & $\begin{array}{l}0.041^{* *} \\
(0.019)\end{array}$ & $\begin{array}{l}0.038^{* *} \\
(0.019)\end{array}$ & $\begin{array}{c}0.028 \\
(0.020)\end{array}$ & $\begin{array}{c}0.029 \\
(0.021)\end{array}$ & $\begin{array}{c}0.033 \\
(0.025)\end{array}$ & $\begin{array}{c}0.024 \\
(0.024)\end{array}$ & $\begin{array}{c}0.026 \\
(0.026)\end{array}$ & $\begin{array}{c}0.043 \\
(0.026)\end{array}$ \\
\hline Time to limited cons. market & $\begin{array}{c}0.562 \\
(0.422)\end{array}$ & & & $\begin{array}{c}0.685 \\
(0.477)\end{array}$ & $\begin{array}{c}0.082 * * * \\
(0.018)\end{array}$ & & & $\begin{array}{c}0.079 * * * \\
(0.018)\end{array}$ \\
\hline Time to periodic market & & $\begin{array}{c}0.039 * * * \\
(0.014)\end{array}$ & & $\begin{array}{l}0.036^{* *} \\
(0.014)\end{array}$ & & $\begin{array}{c}4.026 * * * \\
(1.202)\end{array}$ & & $\begin{array}{r}2.740^{* *} \\
(1.270)\end{array}$ \\
\hline Time to cooperative market & & & $\begin{array}{c}0.012 \\
(0.010)\end{array}$ & $\begin{array}{c}0.011 \\
(0.010)\end{array}$ & & & $\begin{array}{c}1.110 \\
(0.0982)\end{array}$ & $\begin{array}{c}1.102 \\
(0.974)\end{array}$ \\
\hline $\begin{array}{l}\text { DISTRICT FIXED EFFECTS } \\
\text { MONTH OF SURVEY }\end{array}$ & $\begin{array}{l}Y E S \\
Y E S\end{array}$ & $\begin{array}{l}Y E S \\
Y E S\end{array}$ & $\begin{array}{l}Y E S \\
Y E S\end{array}$ & $\begin{array}{l}\text { YES } \\
\text { YES }\end{array}$ & $\begin{array}{l}Y E S \\
Y E S\end{array}$ & $\begin{array}{l}Y E S \\
Y E S\end{array}$ & $\begin{array}{l}\text { YES } \\
\text { YES }\end{array}$ & $\begin{array}{l}\text { YES } \\
\text { YES }\end{array}$ \\
\hline Observations & 5,068 & 5,117 & 5,111 & 5,068 & 5,014 & 5,073 & 5,066 & 5,014 \\
\hline Wald chi2 & 132.7 & 131.4 & 130.9 & 162.8 & 290.0 & 287.1 & 285.6 & 321.5 \\
\hline R squared & 0.0434 & 0.0423 & 0.0422 & 0.0490 & 0.0732 & 0.0724 & 0.0713 & 0.0773 \\
\hline
\end{tabular}


Table 5. Probit regression for economic activity (Marginal effects)

\begin{tabular}{|c|c|c|c|c|c|c|c|c|}
\hline & \multicolumn{4}{|c|}{ Boys } & \multicolumn{4}{|c|}{ Girls } \\
\hline & (i) & (ii) & (iii) & (iv) & (i) & (ii) & (iii) & (iv) \\
\hline \multicolumn{9}{|l|}{ CHILD CHARACTERISTICS } \\
\hline Child’s age & $\begin{array}{c}0.321 * * * \\
(0.017)\end{array}$ & $\begin{array}{c}0.322 * * * \\
(0.017)\end{array}$ & $\begin{array}{c}0.322^{* * *} \\
(0.017)\end{array}$ & $\begin{array}{c}0.320 * * * \\
(0.017)\end{array}$ & $\begin{array}{c}0.273^{* * *} \\
(0.016)\end{array}$ & $\begin{array}{c}0.275^{* * * *} \\
(0.016)\end{array}$ & $\begin{array}{c}0.275^{* * *} \\
(0.016)\end{array}$ & $\begin{array}{c}0.273^{* * *} \\
(0.016)\end{array}$ \\
\hline Age Squared & $\begin{array}{c}-0.016 * * * \\
(0.001)\end{array}$ & $\begin{array}{c}-0.016^{* * *} \\
(0.001)\end{array}$ & $\begin{array}{c}-0.016^{* * *} \\
(0.001)\end{array}$ & $\begin{array}{c}-0.016^{* * *} \\
(0.001)\end{array}$ & $\begin{array}{c}-0.014^{* * *} \\
(0.001)\end{array}$ & $\begin{array}{c}-0.014 * * * \\
(0.001)\end{array}$ & $\begin{array}{c}-0.014 * * * \\
(0.001)\end{array}$ & $\begin{array}{c}-0.014 * * * \\
(0.001)\end{array}$ \\
\hline Mother in the household & $\begin{array}{c}0.006 \\
(0.014) \\
\end{array}$ & $\begin{array}{c}0.007 \\
(0.014) \\
\end{array}$ & $\begin{array}{c}0.008 \\
(0.014) \\
\end{array}$ & $\begin{array}{c}0.006 \\
(0.014) \\
\end{array}$ & $\begin{array}{c}0.016 \\
(0.012) \\
\end{array}$ & $\begin{array}{c}0.014 \\
(0.012) \\
\end{array}$ & $\begin{array}{c}0.015 \\
(0.012) \\
\end{array}$ & $\begin{array}{c}0.016 \\
(0.012) \\
\end{array}$ \\
\hline \multicolumn{9}{|c|}{ HOUSEHOLD CHARACTERISTICS } \\
\hline Dependency ratio & $\begin{array}{c}0.166^{* * *} \\
(0.044)\end{array}$ & $\begin{array}{c}0.162 * * * \\
(0.044)\end{array}$ & $\begin{array}{c}0.162 * * * \\
(0.044)\end{array}$ & $\begin{array}{c}0.169 * * * \\
(0.044)\end{array}$ & $\begin{array}{c}0.054 \\
(0.043)\end{array}$ & $\begin{array}{c}0.057 \\
(0.042)\end{array}$ & $\begin{array}{c}0.055 \\
(0.042)\end{array}$ & $\begin{array}{c}0.053 \\
(0.043)\end{array}$ \\
\hline Age of the head in years & $\begin{array}{c}0.001^{* *} \\
(0.000)\end{array}$ & $\begin{array}{c}0.001 * * \\
(0.000)\end{array}$ & $\begin{array}{c}0.001^{* *} \\
(0.000)\end{array}$ & $\begin{array}{c}0.001^{* *} \\
(0.000)\end{array}$ & $\begin{array}{c}0.002 * * * \\
(0.000)\end{array}$ & $\begin{array}{c}0.002 * * * \\
(0.000)\end{array}$ & $\begin{array}{c}0.002^{* * *} \\
(0.000)\end{array}$ & $\begin{array}{c}0.002^{* * *} \\
(0.000)\end{array}$ \\
\hline Head is female & $\begin{array}{c}0.032 * * \\
(0.015)\end{array}$ & $\begin{array}{c}0.030 * * \\
(0.015)\end{array}$ & $\begin{array}{c}0.030 * * \\
(0.015)\end{array}$ & $\begin{array}{c}0.031 * * \\
(0.015)\end{array}$ & $\begin{array}{c}0.007 \\
(0.013)\end{array}$ & $\begin{array}{c}0.008 \\
(0.013)\end{array}$ & $\begin{array}{c}0.007 \\
(0.013)\end{array}$ & $\begin{array}{c}0.007 \\
(0.013)\end{array}$ \\
\hline Prop.of adults $>$ sec. sch & $\begin{array}{c}-0.005 \\
(0.012)\end{array}$ & $\begin{array}{c}-0.006 \\
(0.012)\end{array}$ & $\begin{array}{c}-0.006 \\
(0.012)\end{array}$ & $\begin{array}{c}-0.005 \\
(0.012)\end{array}$ & $\begin{array}{l}-0.002 \\
(0.011)\end{array}$ & $\begin{array}{c}0.001 \\
(0.011)\end{array}$ & $\begin{array}{l}-0.002 \\
(0.011)\end{array}$ & $\begin{array}{l}-0.002 \\
(0.011)\end{array}$ \\
\hline Hh involved in farming & $\begin{array}{c}0.052 * * * \\
(0.017)\end{array}$ & $\begin{array}{c}0.051 * * * \\
(0.017)\end{array}$ & $\begin{array}{c}0.051^{* * *} \\
(0.017)\end{array}$ & $\begin{array}{c}0.052 * * * \\
(0.017)\end{array}$ & $\begin{array}{c}0.033^{* *} \\
(0.016)\end{array}$ & $\begin{array}{l}0.029^{*} \\
(0.016)\end{array}$ & $\begin{array}{l}0.031^{* *} \\
(0.016)\end{array}$ & $\begin{array}{c}0.033^{* *} \\
(0.016)\end{array}$ \\
\hline Hh has non-farm enterprises & $\begin{array}{l}0.041^{*} \\
(0.024)\end{array}$ & $\begin{array}{c}0.039 \\
(0.024)\end{array}$ & $\begin{array}{c}0.039 \\
(0.024)\end{array}$ & $\begin{array}{c}0.040 \\
(0.024)\end{array}$ & $\begin{array}{c}0.032 \\
(0.022)\end{array}$ & $\begin{array}{c}0.031 \\
(0.022)\end{array}$ & $\begin{array}{c}0.031 \\
(0.022)\end{array}$ & $\begin{array}{c}0.032 \\
(0.022)\end{array}$ \\
\hline Prop. female wage earners & $\begin{array}{l}-0.580^{*} \\
(0.302)\end{array}$ & $\begin{array}{l}-0.584^{*} \\
(0.300)\end{array}$ & $\begin{array}{l}-0.582^{*} \\
(0.300)\end{array}$ & $\begin{array}{l}-0.580^{*} \\
(0.303)\end{array}$ & $\begin{array}{l}-0.207 \\
(0.156)\end{array}$ & $\begin{array}{l}-0.211 \\
(0.156)\end{array}$ & $\begin{array}{l}-0.202 \\
(0.155)\end{array}$ & $\begin{array}{l}-0.208 \\
(0.156)\end{array}$ \\
\hline Prop. male wage earners & $\begin{array}{l}-0.159 \\
(0.127)\end{array}$ & $\begin{array}{c}-0.166 \\
(0.125)\end{array}$ & $\begin{array}{c}-0.166 \\
(0.125)\end{array}$ & $\begin{array}{c}-0.165 \\
(0.127)\end{array}$ & $\begin{array}{c}0.104 \\
(0.108)\end{array}$ & $\begin{array}{c}0.110 \\
(0.107)\end{array}$ & $\begin{array}{c}0.111 \\
(0.108)\end{array}$ & $\begin{array}{c}0.105 \\
(0.108)\end{array}$ \\
\hline Value of assets & $\begin{array}{c}0.600^{* * *} \\
(0.183)\end{array}$ & $\begin{array}{c}0.593 * * * \\
(0.182)\end{array}$ & $\begin{array}{c}0.599 * * * \\
(0.182)\end{array}$ & $\begin{array}{c}0.594 * * * \\
(0.183)\end{array}$ & $\begin{array}{l}-0.139 \\
(0.162)\end{array}$ & $\begin{array}{l}-0.137 \\
(0.161)\end{array}$ & $\begin{array}{l}-0.144 \\
(0.161)\end{array}$ & $\begin{array}{l}-0.141 \\
(0.162)\end{array}$ \\
\hline \multicolumn{9}{|c|}{ COMMUNITY-LEVEL VARIABLES } \\
\hline School in the village & $\begin{array}{c}-0.023^{*} \\
(0.012)\end{array}$ & $\begin{array}{c}-0.024^{* *} \\
(0.012)\end{array}$ & $\begin{array}{l}-0.023^{*} \\
(0.012)\end{array}$ & $\begin{array}{l}-0.022 * \\
(0.012)\end{array}$ & $\begin{array}{l}-0.001 \\
(0.011)\end{array}$ & $\begin{array}{l}-0.001 \\
(0.011)\end{array}$ & $\begin{array}{c}-0.002 \\
(0.011)\end{array}$ & $\begin{array}{c}-0.001 \\
(0.011)\end{array}$ \\
\hline Population density & $\begin{array}{c}0.003 \\
(0.004)\end{array}$ & $\begin{array}{c}0.004 \\
(0.004)\end{array}$ & $\begin{array}{c}0.004 \\
(0.004)\end{array}$ & $\begin{array}{c}0.003 \\
(0.004)\end{array}$ & $\begin{array}{c}0.004 \\
(0.004)\end{array}$ & $\begin{array}{c}0.004 \\
(0.004)\end{array}$ & $\begin{array}{c}0.004 \\
(0.004)\end{array}$ & $\begin{array}{c}0.004 \\
(0.004)\end{array}$ \\
\hline Distance to town & $\begin{array}{l}-0.255 \\
(0.239)\end{array}$ & $\begin{array}{l}-0.270 \\
(0.239)\end{array}$ & $\begin{array}{l}-0.273 \\
(0.239)\end{array}$ & $\begin{array}{l}-0.272 \\
(0.240)\end{array}$ & $\begin{array}{l}-0.081 \\
(0.221)\end{array}$ & $\begin{array}{l}-0.086 \\
(0.222)\end{array}$ & $\begin{array}{l}-0.106 \\
(0.221)\end{array}$ & $\begin{array}{l}-0.084 \\
(0.222)\end{array}$ \\
\hline Time to all-weather road & $\begin{array}{c}0.021 \\
(0.029)\end{array}$ & $\begin{array}{c}0.033 \\
(0.028)\end{array}$ & $\begin{array}{c}0.044 \\
(0.030)\end{array}$ & $\begin{array}{c}0.034 \\
(0.031)\end{array}$ & $\begin{array}{l}0.052 * \\
(0.027)\end{array}$ & $\begin{array}{l}0.051^{*} \\
(0.026)\end{array}$ & $\begin{array}{l}0.060 * * \\
(0.028)\end{array}$ & $\begin{array}{l}0.049 * \\
(0.029)\end{array}$ \\
\hline T. to limited cons. Market & $\begin{array}{c}-2.130 * * * \\
(0.015)\end{array}$ & & & $\begin{array}{c}-2.131^{* * *} \\
(0.015)\end{array}$ & $\begin{array}{l}-1.351^{*} \\
(0.753)\end{array}$ & & & $\begin{array}{l}-1.420^{*} \\
(0.805)\end{array}$ \\
\hline T. to periodic market & & $\begin{array}{c}-0.055^{* * *} \\
(0.021)\end{array}$ & & $\begin{array}{c}-0.060^{* *} \\
(0.023)\end{array}$ & & $\begin{array}{c}-0.049 * * \\
(0.022)\end{array}$ & & $\begin{array}{c}-0.049 * * \\
(0.023)\end{array}$ \\
\hline T. to cooperative market & & & $\begin{array}{l}-0.793 \\
(1.433)\end{array}$ & $\begin{array}{l}-1.230 \\
(1.502)\end{array}$ & & & $\begin{array}{l}-0.719 \\
(0.529)\end{array}$ & $\begin{array}{l}-0.722 \\
(0.561)\end{array}$ \\
\hline $\begin{array}{l}\text { DISTRICT FIXED EFFECTS } \\
\text { MONTH OF SURVEY }\end{array}$ & $\begin{array}{l}\text { YES } \\
Y E S\end{array}$ & $\begin{array}{l}Y E S \\
Y E S\end{array}$ & $\begin{array}{l}\text { YES } \\
\text { YES }\end{array}$ & $\begin{array}{l}Y E S \\
Y E S\end{array}$ & $\begin{array}{l}Y E S \\
Y E S\end{array}$ & $\begin{array}{l}Y E S \\
Y E S\end{array}$ & $\begin{array}{l}Y E S \\
Y E S\end{array}$ & $\begin{array}{l}Y E S \\
Y E S\end{array}$ \\
\hline Observations & 5,068 & 5,117 & 5,111 & 5,068 & 5,014 & 5,073 & 5,066 & 5,014 \\
\hline Wald chi2 & 576.0 & 581.1 & 581.3 & 575.3 & 512.0 & 509.6 & 509.5 & 513.6 \\
\hline R squared & 0.127 & 0.128 & 0.128 & 0.128 & 0.122 & 0.122 & 0.122 & 0.122 \\
\hline
\end{tabular}

Standard errors in parenthesis, * significant at $10 \%$; ** significant at $5 \%$; *** significant at $1 \%$ 
Table 6. Probit regressions for different ages (Marginal effects)

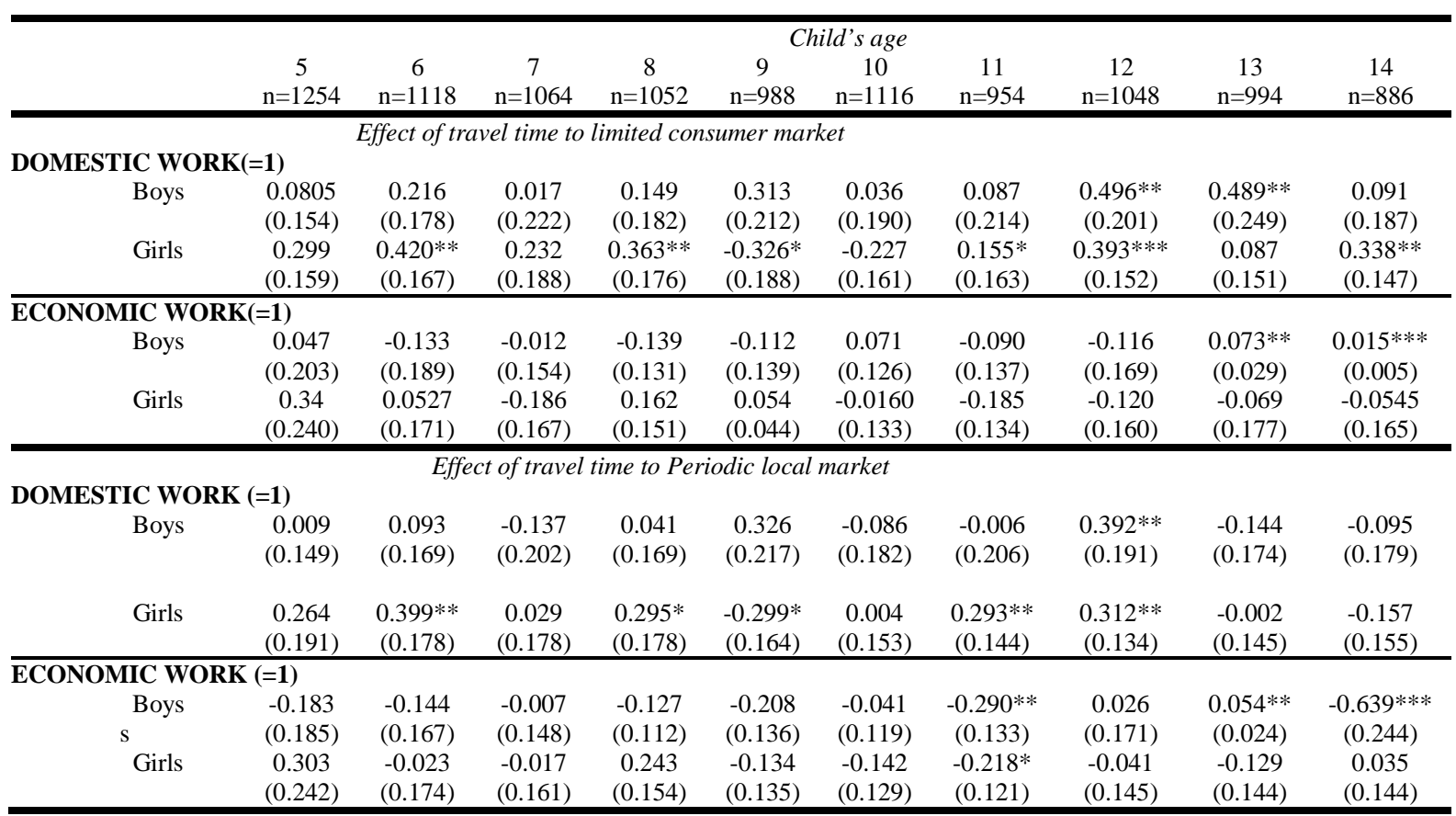

Notes: Standard errors in parenthesis, * implies significant at $10 \%$; ** significant at 5\%; *** significant at $1 \%$. Other variables included but not reported are; age, age squared, mother lives in the household, dependency ratio, age of the head, dummy for female head, proportion of adults above secondary schooling, household involved in farming, household has non-farm enterprise, proportion of female wage earners, proportion of male wage earners, value of assets, school available in the village, distance to nearest town, travel time to all-weather road, month of data collection, district fixed effects.

Table 7. Likelihood Ratio test statistics

\begin{tabular}{llll}
\hline Model & & Test statistic & P-value \\
\hline TOTAL HOURS & Boys & 4825.646 & 0.000 \\
& Girls & 5418.737 & 0.000 \\
\hline DOMESTIC ACTIVITY & & 4986.265 & 0.000 \\
& Boys & 5723.576 & 0.000 \\
\hline ECONOMIC ACTIVITY & Girls & 9551.336 & 0.000 \\
& Boys & 9560.11 & 0.000 \\
\hline
\end{tabular}


Table 8. Cragg's double-hurdle model for the full sample (marginal effects)

\begin{tabular}{|c|c|c|c|c|c|c|c|c|c|c|c|c|}
\hline & \multicolumn{4}{|c|}{ Total } & \multicolumn{4}{|c|}{ Domestic activity } & \multicolumn{4}{|c|}{ Economic activity } \\
\hline & (i) & (ii) & (iii) & (iv) & (i) & (ii) & (iii) & (iv) & (i) & (ii) & (iii) & (iv) \\
\hline \multicolumn{13}{|c|}{ CHILD CHARACTERISTICS } \\
\hline Child's age & $\begin{array}{l}0.253 * * * \\
(0.033)\end{array}$ & $\begin{array}{l}0.251^{* * *} \\
(0.032)\end{array}$ & $\begin{array}{l}0.251^{* * *} \\
(0.032)\end{array}$ & $\begin{array}{l}0.253 * * * \\
(0.033)\end{array}$ & $\begin{array}{l}0.253 * * * \\
(0.033)\end{array}$ & $\begin{array}{l}0.251 * * * \\
(0.032)\end{array}$ & $\begin{array}{l}0.251^{* * *} \\
(0.032)\end{array}$ & $\begin{array}{l}0.253 * * * \\
(0.033)\end{array}$ & $\begin{array}{l}0.998 * * * \\
(0.051)\end{array}$ & $\begin{array}{l}0.999 * * * \\
(0.050)\end{array}$ & $\begin{array}{l}0.999 * * * \\
(0.050)\end{array}$ & $\begin{array}{l}0.998 * * * \\
(0.051)\end{array}$ \\
\hline Age squared & $\begin{array}{l}-0.006 * * * \\
(0.002)\end{array}$ & $\begin{array}{l}-0.006^{* * *} \\
(0.002)\end{array}$ & $\begin{array}{l}-0.006^{* * *} \\
(0.002)\end{array}$ & $\begin{array}{l}-0.006 * * * \\
(0.002)\end{array}$ & $\begin{array}{l}-0.006 * * * \\
(0.002)\end{array}$ & $\begin{array}{l}-0.006^{* * *} \\
(0.002)\end{array}$ & $\begin{array}{l}-0.006 * * * \\
(0.002)\end{array}$ & $\begin{array}{l}-0.006 * * * \\
(0.002)\end{array}$ & $\begin{array}{l}-0.039 * * * \\
(0.003)\end{array}$ & $\begin{array}{l}-0.039 * * * \\
(0.003)\end{array}$ & $\begin{array}{l}-0.039 * * * \\
(0.003)\end{array}$ & $\begin{array}{l}-0.039 * * * \\
(0.003)\end{array}$ \\
\hline Mother in household & $\begin{array}{l}-0.093 * * * \\
(0.026)\end{array}$ & $\begin{array}{l}-0.091^{* * *} \\
(0.026)\end{array}$ & $\begin{array}{l}-0.089 * * * \\
(0.026)\end{array}$ & $\begin{array}{l}-0.093^{* * *} \\
(0.026)\end{array}$ & $\begin{array}{l}-0.093 * * * \\
(0.026)\end{array}$ & $\begin{array}{l}-0.091^{* * *} \\
(0.026)\end{array}$ & $\begin{array}{l}-0.089 * * * \\
(0.026)\end{array}$ & $\begin{array}{l}-0.093 * * * \\
(0.026)\end{array}$ & $\begin{array}{l}-0.234 * * * \\
(0.042)\end{array}$ & $\begin{array}{l}-0.238 * * * \\
(0.042)\end{array}$ & $\begin{array}{l}-0.239 * * * \\
(0.042)\end{array}$ & $\begin{array}{l}-0.233^{* * *} \\
(0.042)\end{array}$ \\
\hline \multicolumn{13}{|c|}{ HOUSEHOLD CHARACTERISTICS } \\
\hline Dependency ratio & $\begin{array}{l}0.375^{* * *} \\
(0.085)\end{array}$ & $\begin{array}{l}0.396 * * * \\
(0.085)\end{array}$ & $\begin{array}{l}0.392 * * * \\
(0.085)\end{array}$ & $\begin{array}{l}0.380 * * * \\
(0.086)\end{array}$ & $\begin{array}{l}0.375^{* * *} \\
(0.085)\end{array}$ & $\begin{array}{l}0.396 * * * \\
(0.085)\end{array}$ & $\begin{array}{l}0.392 * * * \\
(0.085)\end{array}$ & $\begin{array}{l}0.380^{* * *} \\
(0.086)\end{array}$ & $\begin{array}{l}0.413^{* * *} \\
(0.139)\end{array}$ & $\begin{array}{l}0.413^{* * *} \\
(0.139)\end{array}$ & $\begin{array}{l}0.416^{* * *} \\
(0.139)\end{array}$ & $\begin{array}{l}0.422 * * * \\
(0.139)\end{array}$ \\
\hline Age of the head & $\begin{array}{l}-0.002^{* * *} \\
(0.001)\end{array}$ & $\begin{array}{l}-0.002^{* * *} \\
(0.001)\end{array}$ & $\begin{array}{l}-0.002 * * * \\
(0.001)\end{array}$ & $\begin{array}{l}-0.003^{* * *} \\
(0.001)\end{array}$ & $\begin{array}{l}-0.002 * * * \\
(0.001)\end{array}$ & $\begin{array}{l}-0.002^{* * *} \\
(0.001)\end{array}$ & $\begin{array}{l}-0.002 * * * \\
(0.001)\end{array}$ & $\begin{array}{l}-0.003^{* * *} \\
(0.001)\end{array}$ & $\begin{array}{l}-0.006^{* * *} \\
(0.001)\end{array}$ & $\begin{array}{l}-0.006^{* * *} \\
(0.001)\end{array}$ & $\begin{array}{l}-0.006 * * * \\
(0.001)\end{array}$ & $\begin{array}{l}-0.006 * * * \\
(0.001)\end{array}$ \\
\hline Head is female & $\begin{array}{l}-0.029 \\
(0.027)\end{array}$ & $\begin{array}{l}-0.037 \\
(0.027)\end{array}$ & $\begin{array}{l}-0.036 \\
(0.027)\end{array}$ & $\begin{array}{l}-0.030 \\
(0.027)\end{array}$ & $\begin{array}{l}-0.029 \\
(0.027)\end{array}$ & $\begin{array}{l}-0.037 \\
(0.027)\end{array}$ & $\begin{array}{l}-0.036 \\
(0.027)\end{array}$ & $\begin{array}{l}-0.030 \\
(0.027)\end{array}$ & $\begin{array}{l}-0.029 \\
(0.044)\end{array}$ & $\begin{array}{l}-0.035 \\
(0.044)\end{array}$ & $\begin{array}{l}-0.035 \\
(0.044)\end{array}$ & $\begin{array}{l}-0.031 \\
(0.044)\end{array}$ \\
\hline Prop. adults $>$ sec. sch & $\begin{array}{l}-0.034 \\
(0.026)\end{array}$ & $\begin{array}{l}-0.034 \\
(0.026)\end{array}$ & $\begin{array}{l}-0.035 \\
(0.026)\end{array}$ & $\begin{array}{l}-0.035 \\
(0.026)\end{array}$ & $\begin{array}{l}-0.034 \\
(0.026)\end{array}$ & $\begin{array}{l}-0.034 \\
(0.026)\end{array}$ & $\begin{array}{l}-0.035 \\
(0.026)\end{array}$ & $\begin{array}{l}-0.035 \\
(0.026)\end{array}$ & $\begin{array}{l}-0.226^{* * *} \\
(0.040)\end{array}$ & $\begin{array}{l}-0.233^{* * *} \\
(0.040)\end{array}$ & $\begin{array}{l}-0.226^{* * *} \\
(0.040)\end{array}$ & $\begin{array}{l}-0.228 * * * \\
(0.040)\end{array}$ \\
\hline Hh in farming & $\begin{array}{l}0.035 \\
(0.033)\end{array}$ & $\begin{array}{l}0.037 \\
(0.033)\end{array}$ & $\begin{array}{l}0.038 \\
(0.033)\end{array}$ & $\begin{array}{l}0.037 \\
(0.034)\end{array}$ & $\begin{array}{l}0.035 \\
(0.033)\end{array}$ & $\begin{array}{l}0.037 \\
(0.033)\end{array}$ & $\begin{array}{l}0.038 \\
(0.033)\end{array}$ & $\begin{array}{l}0.037 \\
(0.034)\end{array}$ & $\begin{array}{l}-0.062 \\
(0.054)\end{array}$ & $\begin{array}{l}-0.057 \\
(0.054)\end{array}$ & $\begin{array}{l}-0.065 \\
(0.054)\end{array}$ & $\begin{array}{l}-0.059 \\
(0.054)\end{array}$ \\
\hline Hh non-farm ent. & $\begin{array}{l}0.047 \\
(0.044)\end{array}$ & $\begin{array}{l}0.049 \\
(0.043)\end{array}$ & $\begin{array}{l}0.050 \\
(0.043)\end{array}$ & $\begin{array}{l}0.048 \\
(0.044)\end{array}$ & $\begin{array}{l}0.047 \\
(0.044)\end{array}$ & $\begin{array}{l}0.049 \\
(0.043)\end{array}$ & $\begin{array}{l}0.050 \\
(0.043)\end{array}$ & $\begin{array}{l}0.048 \\
(0.044)\end{array}$ & $\begin{array}{l}-0.179 * * \\
(0.072)\end{array}$ & $\begin{array}{l}-0.174^{* *} \\
(0.072)\end{array}$ & $\begin{array}{l}-0.181^{* *} \\
(0.072)\end{array}$ & $\begin{array}{l}-0.178 * * \\
(0.072)\end{array}$ \\
\hline Prop. f. wage earners & $\begin{array}{l}0.439 \\
(0.297)\end{array}$ & $\begin{array}{l}0.422 \\
(0.299)\end{array}$ & $\begin{array}{l}0.447 \\
(0.298)\end{array}$ & $\begin{array}{l}0.416 \\
(0.298)\end{array}$ & $\begin{array}{l}0.439 \\
(0.297)\end{array}$ & $\begin{array}{l}0.422 \\
(0.299)\end{array}$ & $\begin{array}{l}0.447 \\
(0.298)\end{array}$ & $\begin{array}{l}0.416 \\
(0.298)\end{array}$ & $\begin{array}{l}-0.308 \\
(0.505)\end{array}$ & $\begin{array}{l}-0.326 \\
(0.505)\end{array}$ & $\begin{array}{l}-0.316 \\
(0.505)\end{array}$ & $\begin{array}{l}-0.349 \\
(0.505)\end{array}$ \\
\hline Prop. m. wage earners & $\begin{array}{l}0.446 * \\
(0.232)\end{array}$ & $\begin{array}{l}0.483^{* *} \\
(0.228)\end{array}$ & $\begin{array}{l}0.480 * * \\
(0.229)\end{array}$ & $\begin{array}{l}0.446 * \\
(0.232)\end{array}$ & $\begin{array}{l}0.446 * \\
(0.232)\end{array}$ & $\begin{array}{l}0.483 * * \\
(0.228)\end{array}$ & $\begin{array}{l}0.480 * * \\
(0.229)\end{array}$ & $\begin{array}{l}0.446 * \\
(0.232)\end{array}$ & $\begin{array}{l}-0.515 \\
(0.398)\end{array}$ & $\begin{array}{l}-0.446 \\
(0.393)\end{array}$ & $\begin{array}{l}-0.478 \\
(0.394)\end{array}$ & $\begin{array}{l}-0.524 \\
(0.397)\end{array}$ \\
\hline Value of assets & $\begin{array}{l}-0.330 \\
(0.339) \\
\end{array}$ & $\begin{array}{l}-0.368 \\
(0.337) \\
\end{array}$ & $\begin{array}{l}-0.344 \\
(0.336)\end{array}$ & $\begin{array}{l}-0.359 \\
(0.339)\end{array}$ & $\begin{array}{l}-0.330 \\
(0.339)\end{array}$ & $\begin{array}{l}-0.368 \\
(0.337)\end{array}$ & $\begin{array}{l}-0.344 \\
(0.336)\end{array}$ & $\begin{array}{l}-0.359 \\
(0.339)\end{array}$ & $\begin{array}{l}-3.179 * * * \\
(0.547)\end{array}$ & $\begin{array}{l}-3.122 * * * \\
(0.547)\end{array}$ & $\begin{array}{l}-3.037 * * * \\
(0.546)\end{array}$ & $\begin{array}{l}-3.231 * * * \\
(0.548)\end{array}$ \\
\hline \multicolumn{13}{|c|}{ COMMUNITY-LEVEL VARIABLES } \\
\hline School in the village & $\begin{array}{l}-0.129 * * * \\
(0.023)\end{array}$ & $\begin{array}{l}-0.129 * * * \\
(0.023)\end{array}$ & $\begin{array}{l}-0.128 * * * \\
(0.023)\end{array}$ & $\begin{array}{l}-0.128 * * * \\
(0.023)\end{array}$ & $\begin{array}{l}-0.129 * * * \\
(0.023)\end{array}$ & $\begin{array}{l}-0.129 * * * \\
(0.023)\end{array}$ & $\begin{array}{l}-0.128 * * * \\
(0.023)\end{array}$ & $\begin{array}{l}-0.128 * * * \\
(0.023)\end{array}$ & $\begin{array}{l}0.038 \\
(0.037)\end{array}$ & $\begin{array}{l}0.039 \\
(0.037)\end{array}$ & $\begin{array}{l}0.043 \\
(0.037)\end{array}$ & $\begin{array}{l}0.039 \\
(0.037)\end{array}$ \\
\hline Population density & $\begin{array}{l}0.025^{* * *} \\
(0.008)\end{array}$ & $\begin{array}{l}0.027^{* * *} \\
(0.008)\end{array}$ & $\begin{array}{l}0.026 * * * \\
(0.008)\end{array}$ & $\begin{array}{l}0.026^{* * *} \\
(0.008)\end{array}$ & $\begin{array}{l}-0.025^{* * *} \\
(0.008)\end{array}$ & $\begin{array}{l}-0.027^{* * *} \\
(0.008)\end{array}$ & $\begin{array}{l}-0.026 * * * \\
(0.008)\end{array}$ & $\begin{array}{l}-0.026^{* * *} \\
(0.008)\end{array}$ & $\begin{array}{l}-0.005 \\
(0.014)\end{array}$ & $\begin{array}{l}-0.011 \\
(0.013)\end{array}$ & $\begin{array}{l}-0.010 \\
(0.013)\end{array}$ & $\begin{array}{l}-0.007 \\
(0.014)\end{array}$ \\
\hline Distance to town & $\begin{array}{l}0.745 \\
(0.463)\end{array}$ & $\begin{array}{l}0.655 \\
(0.462)\end{array}$ & $\begin{array}{l}0.710 \\
(0.461)\end{array}$ & $\begin{array}{l}0.681 \\
(0.463)\end{array}$ & $\begin{array}{l}0.745 \\
(0.463)\end{array}$ & $\begin{array}{l}0.655 \\
(0.462)\end{array}$ & $\begin{array}{l}0.710 \\
(0.461)\end{array}$ & $\begin{array}{l}0.681 \\
(0.463)\end{array}$ & $\begin{array}{l}1.334^{*} \\
(0.774)\end{array}$ & $\begin{array}{l}1.034 \\
(0.775)\end{array}$ & $\begin{array}{l}1.166 \\
(0.773)\end{array}$ & $\begin{array}{l}1.229 \\
(0.775)\end{array}$ \\
\hline T. to all-weather road & $\begin{array}{l}0.020 \\
(0.055)\end{array}$ & $\begin{array}{l}0.025 \\
(0.053)\end{array}$ & $\begin{array}{l}0.032 \\
(0.057)\end{array}$ & $\begin{array}{l}0.028 \\
(0.059)\end{array}$ & $\begin{array}{l}0.020 \\
(0.055)\end{array}$ & $\begin{array}{l}0.025 \\
(0.053)\end{array}$ & $\begin{array}{l}0.032 \\
(0.057)\end{array}$ & $\begin{array}{l}0.028 \\
(0.059)\end{array}$ & $\begin{array}{l}0.047 \\
(0.090)\end{array}$ & $\begin{array}{l}0.063 \\
(0.088)\end{array}$ & $\begin{array}{l}0.081 \\
(0.094)\end{array}$ & $\begin{array}{l}0.071 \\
(0.097)\end{array}$ \\
\hline T. limited market & $\begin{array}{l}0.231 * * * \\
(0.063)\end{array}$ & & & $\begin{array}{l}0.227 * * * \\
(0.063)\end{array}$ & $\begin{array}{l}0.207 * * * \\
(0.067)\end{array}$ & & & $\begin{array}{l}0.201 * * * \\
(0.067)\end{array}$ & $\begin{array}{l}-0.335 \\
(2.584)\end{array}$ & & & $\begin{array}{l}-0.936 \\
(2.722)\end{array}$ \\
\hline T. to periodic market & & $\begin{array}{l}5.326 * \\
(2.762)\end{array}$ & & $\begin{array}{l}5.633^{*} \\
(2.909)\end{array}$ & & $\begin{array}{l}0.362 * * * \\
(0.062)\end{array}$ & & $\begin{array}{l}0.357 * * * \\
(0.063)\end{array}$ & & $\begin{array}{l}-2.773^{* *} \\
(0.503)\end{array}$ & & $\begin{array}{l}-2.290 * * \\
(0.690)\end{array}$ \\
\hline T. to coop. market & & & $\begin{array}{l}-6.919 \\
(18.526)\end{array}$ & $\begin{array}{l}-8.387 \\
(19.384)\end{array}$ & & & $\begin{array}{l}0.055 \\
(0.070)\end{array}$ & $\begin{array}{l}0.044 \\
(0.071)\end{array}$ & & & $\begin{array}{l}-0.802 \\
(0.959)\end{array}$ & $\begin{array}{l}-0.648 \\
(0.958)\end{array}$ \\
\hline DISTRICT F E & YES & YES & YES & YES & YES & YES & YES & YES & $Y E S$ & YES & YES & YES \\
\hline MONTH OF SURVEY & YES & YES & YES & YES & YES & YES & YES & YES & YES & YES & YES & YES \\
\hline Observations & 9,492 & 9,595 & 9,583 & 9,492 & 9,492 & 9,595 & 9,583 & 9,492 & 9,454 & 9,557 & 9,545 & 9,454 \\
\hline Wald chi2 & 1332 & 1352 & 1350 & 1338 & 1332 & 1352 & 1350 & 1338 & 1332 & 1352 & 1350 & 1338 \\
\hline
\end{tabular}


Table 9. Cragg's double-hurdle model of total hours of child work (marginal effects)

\begin{tabular}{|c|c|c|c|c|c|c|c|c|}
\hline & \multicolumn{4}{|c|}{ Boys } & \multicolumn{4}{|c|}{ Girls } \\
\hline & (i) & (ii) & (iii) & (iv) & (i) & (ii) & (iii) & (iv) \\
\hline \multicolumn{9}{|l|}{ CHILD CHARACTERISTICS } \\
\hline Child's age & $\begin{array}{l}0.272 * * * \\
(0.047)\end{array}$ & $\begin{array}{l}0.263 * * * \\
(0.046)\end{array}$ & $\begin{array}{l}0.264 * * * \\
(0.046)\end{array}$ & $\begin{array}{l}0.272 * * * \\
(0.047)\end{array}$ & $\begin{array}{l}0.219 * * * \\
(0.044)\end{array}$ & $\begin{array}{l}0.222 * * * \\
(0.044)\end{array}$ & $\begin{array}{l}0.220 * * * \\
(0.044)\end{array}$ & $\begin{array}{l}0.272 * * * \\
(0.047)\end{array}$ \\
\hline \multirow[t]{2}{*}{ Age squared } & $\begin{array}{l}-0.008^{* * *} \\
(0.002)\end{array}$ & $\begin{array}{l}-0.007 * * * \\
(0.002)\end{array}$ & $\begin{array}{l}-0.007 * * * \\
(0.002)\end{array}$ & $\begin{array}{l}-0.008 * * * \\
(0.002)\end{array}$ & $\begin{array}{l}-0.003 \\
(0.002)\end{array}$ & $\begin{array}{l}-0.003 \\
(0.002)\end{array}$ & $\begin{array}{l}-0.003 \\
(0.002)\end{array}$ & $\begin{array}{l}-0.008 * * * \\
(0.002)\end{array}$ \\
\hline & $-0.082 * *$ & $-0.079 * *$ & $-0.079 * *$ & $-0.082 * *$ & $-0.096 * * *$ & $-0.095 * * *$ & $-0.092 * * *$ & $-0.082 * *$ \\
\hline Mother in the household & $(0.037)$ & $(0.037)$ & $(0.037)$ & $(0.037)$ & $(0.035)$ & $(0.035)$ & $(0.035)$ & $(0.037)$ \\
\hline \multicolumn{9}{|c|}{ HOUSEHOLD CHARACTERISTICS } \\
\hline Dependency ratio & $\begin{array}{l}0.395^{* * *} \\
(0.119)\end{array}$ & $\begin{array}{l}0.408 * * * \\
(0.119)\end{array}$ & $\begin{array}{l}0.408 * * * \\
(0.119)\end{array}$ & $\begin{array}{l}0.398 * * * \\
(0.119)\end{array}$ & $\begin{array}{l}0.302 * * \\
(0.120)\end{array}$ & $\begin{array}{l}0.329 * * * \\
(0.119)\end{array}$ & $\begin{array}{l}0.330 * * * \\
(0.119)\end{array}$ & $\begin{array}{l}0.398 * * * \\
(0.119)\end{array}$ \\
\hline Age of the head in years & $\begin{array}{l}-0.002 \\
(0.001)\end{array}$ & $\begin{array}{l}-0.002 \\
(0.001)\end{array}$ & $\begin{array}{l}-0.002 \\
(0.001)\end{array}$ & $\begin{array}{l}-0.002 \\
(0.001)\end{array}$ & $\begin{array}{l}-0.002^{* *} \\
(0.001)\end{array}$ & $\begin{array}{l}-0.002 * \\
(0.001)\end{array}$ & $\begin{array}{l}-0.002 * \\
(0.001)\end{array}$ & $\begin{array}{l}-0.002 \\
(0.001)\end{array}$ \\
\hline Head is female & $\begin{array}{l}-0.051 \\
(0.039)\end{array}$ & $\begin{array}{l}-0.061 \\
(0.039)\end{array}$ & $\begin{array}{l}-0.061 \\
(0.039)\end{array}$ & $\begin{array}{l}-0.051 \\
(0.039)\end{array}$ & $\begin{array}{l}-0.018 \\
(0.038)\end{array}$ & $\begin{array}{l}-0.024 \\
(0.037)\end{array}$ & $\begin{array}{l}-0.023 \\
(0.037)\end{array}$ & $\begin{array}{l}-0.051 \\
(0.039)\end{array}$ \\
\hline Prop.of adults above sec. sch & $\begin{array}{l}-0.004 \\
(0.037)\end{array}$ & $\begin{array}{l}-0.005 \\
(0.037)\end{array}$ & $\begin{array}{l}-0.004 \\
(0.037)\end{array}$ & $\begin{array}{l}-0.003 \\
(0.037)\end{array}$ & $\begin{array}{l}-0.061^{*} \\
(0.035)\end{array}$ & $\begin{array}{l}-0.060 * \\
(0.035)\end{array}$ & $\begin{array}{l}-0.063^{*} \\
(0.035)\end{array}$ & $\begin{array}{l}-0.003 \\
(0.037)\end{array}$ \\
\hline Hh involved in farming & $\begin{array}{l}0.036 \\
(0.048)\end{array}$ & $\begin{array}{l}0.041 \\
(0.047)\end{array}$ & $\begin{array}{l}0.041 \\
(0.047)\end{array}$ & $\begin{array}{l}0.037 \\
(0.048)\end{array}$ & $\begin{array}{l}0.028 \\
(0.045)\end{array}$ & $\begin{array}{l}0.031 \\
(0.045)\end{array}$ & $\begin{array}{l}0.032 \\
(0.045)\end{array}$ & $\begin{array}{l}0.037 \\
(0.048)\end{array}$ \\
\hline Hh has non-farm enterprises & $\begin{array}{l}0.093 \\
(0.063)\end{array}$ & $\begin{array}{l}0.096 \\
(0.063)\end{array}$ & $\begin{array}{l}0.096 \\
(0.063)\end{array}$ & $\begin{array}{l}0.093 \\
(0.063)\end{array}$ & $\begin{array}{l}-0.007 \\
(0.059)\end{array}$ & $\begin{array}{l}-0.002 \\
(0.059)\end{array}$ & $\begin{array}{l}-0.003 \\
(0.059)\end{array}$ & $\begin{array}{l}0.093 \\
(0.063)\end{array}$ \\
\hline Prop. female wage earners & $\begin{array}{l}0.691 \\
(0.455)\end{array}$ & $\begin{array}{l}0.697 \\
(0.457)\end{array}$ & $\begin{array}{l}0.700 \\
(0.456)\end{array}$ & $\begin{array}{l}0.689 \\
(0.457)\end{array}$ & $\begin{array}{l}0.153 \\
(0.385)\end{array}$ & $\begin{array}{l}0.100 \\
(0.385)\end{array}$ & $\begin{array}{l}0.150 \\
(0.386)\end{array}$ & $\begin{array}{l}0.689 \\
(0.457)\end{array}$ \\
\hline Prop. male wage earners & $\begin{array}{l}-0.101 \\
(0.328)\end{array}$ & $\begin{array}{l}-0.032 \\
(0.319)\end{array}$ & $\begin{array}{l}-0.047 \\
(0.320)\end{array}$ & $\begin{array}{l}-0.106 \\
(0.328)\end{array}$ & $\begin{array}{l}0.724 * * \\
(0.317)\end{array}$ & $\begin{array}{l}0.766 * * \\
(0.314)\end{array}$ & $\begin{array}{l}0.760 * * \\
(0.315)\end{array}$ & $\begin{array}{l}-0.106 \\
(0.328)\end{array}$ \\
\hline Value of assets & $\begin{array}{l}0.090 \\
(0.467)\end{array}$ & $\begin{array}{l}0.064 \\
(0.465)\end{array}$ & $\begin{array}{l}0.052 \\
(0.464)\end{array}$ & $\begin{array}{l}0.082 \\
(0.468)\end{array}$ & $\begin{array}{l}-0.782 * \\
(0.444)\end{array}$ & $\begin{array}{l}-0.835^{*} \\
(0.441)\end{array}$ & $\begin{array}{l}-0.790 * \\
(0.443)\end{array}$ & $\begin{array}{l}0.082 \\
(0.468)\end{array}$ \\
\hline \multicolumn{9}{|c|}{ COMMUNITY-LEVEL VARIABLES } \\
\hline School in the village & $\begin{array}{l}-0.139 * * * \\
(0.033)\end{array}$ & $\begin{array}{l}-0.143^{* * *} \\
(0.033)\end{array}$ & $\begin{array}{l}-0.141^{* * *} \\
(0.033)\end{array}$ & $\begin{array}{l}-0.138 * * * \\
(0.033)\end{array}$ & $\begin{array}{l}-0.132 \text { *** } \\
(0.032)\end{array}$ & $\begin{array}{l}-0.128^{* * *} \\
(0.031)\end{array}$ & $\begin{array}{l}-0.128 * * * \\
(0.031)\end{array}$ & $\begin{array}{l}-0.138 * * * \\
(0.033)\end{array}$ \\
\hline Population density & $\begin{array}{l}-0.033^{* * *} \\
(0.011)\end{array}$ & $\begin{array}{l}-0.032 * * * \\
(0.011)\end{array}$ & $\begin{array}{l}-0.032 \text { *** } \\
(0.011)\end{array}$ & $\begin{array}{l}-0.033^{* * *} \\
(0.011)\end{array}$ & $\begin{array}{l}-0.021 * \\
(0.011)\end{array}$ & $\begin{array}{l}-0.026 * * \\
(0.011)\end{array}$ & $\begin{array}{l}-0.024 * * \\
(0.011)\end{array}$ & $\begin{array}{l}-0.033 * * * \\
(0.011)\end{array}$ \\
\hline Distance to town & $\begin{array}{l}0.488 \\
(0.647)\end{array}$ & $\begin{array}{l}0.454 \\
(0.646)\end{array}$ & $\begin{array}{l}0.450 \\
(0.645)\end{array}$ & $\begin{array}{l}0.472 \\
(0.648)\end{array}$ & $\begin{array}{l}0.940 \\
(0.649)\end{array}$ & $\begin{array}{l}0.780 \\
(0.648)\end{array}$ & $\begin{array}{l}0.923 \\
(0.645)\end{array}$ & $\begin{array}{l}0.472 \\
(0.648)\end{array}$ \\
\hline Time to all-weather road & $\begin{array}{l}-0.119 \\
(0.077)\end{array}$ & $\begin{array}{l}-0.100 \\
(0.074)\end{array}$ & $\begin{array}{l}-0.091 \\
(0.081)\end{array}$ & $\begin{array}{l}-0.108 \\
(0.084)\end{array}$ & $\begin{array}{l}0.152 * * \\
(0.074)\end{array}$ & $\begin{array}{l}0.147 * * \\
(0.072)\end{array}$ & $\begin{array}{l}0.155 * * \\
(0.077)\end{array}$ & $\begin{array}{l}-0.108 \\
(0.084)\end{array}$ \\
\hline Time to limited cons. market & $\begin{array}{l}0.220 * * \\
(0.094)\end{array}$ & & & $\begin{array}{l}0.211^{* *} \\
(0.095)\end{array}$ & $\begin{array}{l}0.154^{*} \\
(0.085)\end{array}$ & & & $\begin{array}{l}0.153 \\
(0.085)\end{array}$ \\
\hline Time to periodic market & & $\begin{array}{l}0.345^{* * *} \\
(0.043)\end{array}$ & & $\begin{array}{l}0.344^{* * *} \\
(0.043)\end{array}$ & & $\begin{array}{l}0.213^{* * *} \\
(0.079)\end{array}$ & & $\begin{array}{l}0.194 * * \\
(0.079)\end{array}$ \\
\hline Time to cooperative market & & & $\begin{array}{l}-0.103 \\
(0.094)\end{array}$ & $\begin{array}{l}-0.097 \\
(0.096)\end{array}$ & & & $\begin{array}{l}0.048 \\
(0.085)\end{array}$ & $\begin{array}{l}0.061 \\
(0.085)\end{array}$ \\
\hline DISTRICT FIXED EFFECTS & YES & YES & YES & YES & YES & YES & YES & YES \\
\hline MONTH OF SURVEY & YES & YES & YES & YES & YES & YES & YES & YES \\
\hline Observations & 4,779 & 4,827 & 4,821 & 4,779 & 4,713 & 4,768 & 4,762 & 4,779 \\
\hline Wald chi2 & 692.9 & 709.2 & 705.0 & 697.0 & 702.3 & 708.7 & 710.4 & 697.0 \\
\hline
\end{tabular}

Notes: Standard errors in parenthesis, * significant at $10 \%$; ** significant at $5 \%$; *** significant at $1 \%$ 
Table 10. Cragg's double-hurdle model of hours of domestic activity (Marginal effects)

\begin{tabular}{|c|c|c|c|c|c|c|c|c|}
\hline & \multicolumn{4}{|c|}{ Boys } & \multicolumn{4}{|c|}{ Girls } \\
\hline & (i) & (ii) & (iii) & (iv) & (i) & (ii) & (iii) & (iv) \\
\hline \multicolumn{9}{|l|}{ CHILD CHARACTERISTICS } \\
\hline Child's age & $\begin{array}{l}0.190 * * * \\
(0.047)\end{array}$ & $\begin{array}{l}0.178 * * * \\
(0.046)\end{array}$ & $\begin{array}{l}0.179 * * * \\
(0.046)\end{array}$ & $\begin{array}{l}0.189 * * * \\
(0.047)\end{array}$ & $\begin{array}{l}0.162 * * * \\
(0.044)\end{array}$ & $\begin{array}{l}0.166 * * * \\
(0.044)\end{array}$ & $\begin{array}{l}0.164 * * * \\
(0.044)\end{array}$ & $\begin{array}{l}0.163^{* * *} \\
(0.044)\end{array}$ \\
\hline Age Squared & $\begin{array}{l}-0.006^{* *} \\
(0.002)\end{array}$ & $\begin{array}{l}-0.005^{* *} \\
(0.002)\end{array}$ & $\begin{array}{l}-0.005^{* *} \\
(0.002)\end{array}$ & $\begin{array}{l}-0.006^{* *} \\
(0.002)\end{array}$ & $\begin{array}{l}-0.001 \\
(0.002)\end{array}$ & $\begin{array}{l}-0.002 \\
(0.002)\end{array}$ & $\begin{array}{l}-0.001 \\
(0.002)\end{array}$ & $\begin{array}{l}-0.001 \\
(0.002)\end{array}$ \\
\hline Mother in the household & $\begin{array}{l}-0.065^{*} \\
(0.037)\end{array}$ & $\begin{array}{l}-0.066^{*} \\
(0.037)\end{array}$ & $\begin{array}{l}-0.065^{*} \\
(0.037)\end{array}$ & $\begin{array}{l}-0.065^{*} \\
(0.037)\end{array}$ & $\begin{array}{l}-0.098 * * * \\
(0.035)\end{array}$ & $\begin{array}{l}-0.094^{* * *} \\
(0.035)\end{array}$ & $\begin{array}{l}-0.093^{* * *} \\
(0.035)\end{array}$ & $\begin{array}{l}-0.095^{* * *} \\
(0.035)\end{array}$ \\
\hline \multicolumn{9}{|c|}{ HOUSEHOLD CHARACTERISTICS } \\
\hline Dependency ratio & $\begin{array}{l}0.345^{* * *} \\
(0.118)\end{array}$ & $\begin{array}{l}0.366^{* * *} \\
(0.118)\end{array}$ & $\begin{array}{l}0.361^{* * *} \\
(0.118)\end{array}$ & $\begin{array}{l}0.352 * * * \\
(0.118)\end{array}$ & $\begin{array}{l}0.238 * * \\
(0.117)\end{array}$ & $\begin{array}{l}0.257 * * \\
(0.117)\end{array}$ & $\begin{array}{l}0.265^{* *} \\
(0.117)\end{array}$ & $\begin{array}{l}0.242 * * \\
(0.117)\end{array}$ \\
\hline Age of the head in years & $\begin{array}{l}-0.004^{* * *} \\
(0.001)\end{array}$ & $\begin{array}{l}-0.004^{* * *} \\
(0.001)\end{array}$ & $\begin{array}{l}-0.004^{* * *} \\
(0.001)\end{array}$ & $\begin{array}{l}-0.004^{* * *} \\
(0.001)\end{array}$ & $\begin{array}{l}-0.004^{* * *} \\
(0.001)\end{array}$ & $\begin{array}{l}-0.004^{* * *} \\
(0.001)\end{array}$ & $\begin{array}{l}-0.004^{* * *} \\
(0.001)\end{array}$ & $\begin{array}{l}-0.004^{* * *} \\
(0.001)\end{array}$ \\
\hline Head is female & $\begin{array}{l}-0.081^{* *} \\
(0.039)\end{array}$ & $\begin{array}{l}-0.090 * * \\
(0.039)\end{array}$ & $\begin{array}{l}-0.089 * * \\
(0.039)\end{array}$ & $\begin{array}{l}-0.082^{* *} \\
(0.039)\end{array}$ & $\begin{array}{l}-0.015 \\
(0.037)\end{array}$ & $\begin{array}{l}-0.020 \\
(0.037)\end{array}$ & $\begin{array}{l}-0.020 \\
(0.037)\end{array}$ & $\begin{array}{l}-0.017 \\
(0.037)\end{array}$ \\
\hline Prop.of adults $>$ sec. sch & $\begin{array}{l}-0.036 \\
(0.036)\end{array}$ & $\begin{array}{l}-0.039 \\
(0.036)\end{array}$ & $\begin{array}{l}-0.038 \\
(0.036)\end{array}$ & $\begin{array}{l}-0.036 \\
(0.036)\end{array}$ & $\begin{array}{l}-0.096 * * * \\
(0.034)\end{array}$ & $\begin{array}{l}-0.101^{* * *} \\
(0.034)\end{array}$ & $\begin{array}{l}-0.099 * * * \\
(0.034)\end{array}$ & $\begin{array}{l}-0.100 * * * \\
(0.034)\end{array}$ \\
\hline Hh involved in farming & $\begin{array}{l}-0.053 \\
(0.048)\end{array}$ & $\begin{array}{l}-0.046 \\
(0.047)\end{array}$ & $\begin{array}{l}-0.045 \\
(0.047)\end{array}$ & $\begin{array}{l}-0.052 \\
(0.048)\end{array}$ & $\begin{array}{l}0.016 \\
(0.045)\end{array}$ & $\begin{array}{l}0.026 \\
(0.045)\end{array}$ & $\begin{array}{l}0.022 \\
(0.045)\end{array}$ & $\begin{array}{l}0.021 \\
(0.045)\end{array}$ \\
\hline Hh non-farm enterprises & $\begin{array}{l}-0.000 \\
(0.062)\end{array}$ & $\begin{array}{l}0.002 \\
(0.062)\end{array}$ & $\begin{array}{l}0.004 \\
(0.062)\end{array}$ & $\begin{array}{l}-0.001 \\
(0.062)\end{array}$ & $\begin{array}{l}-0.052 \\
(0.060)\end{array}$ & $\begin{array}{l}-0.041 \\
(0.060)\end{array}$ & $\begin{array}{l}-0.046 \\
(0.060)\end{array}$ & $\begin{array}{l}-0.049 \\
(0.060)\end{array}$ \\
\hline Prop. fem wage earners & $\begin{array}{l}0.732 \\
(0.472)\end{array}$ & $\begin{array}{l}0.712 \\
(0.472)\end{array}$ & $\begin{array}{l}0.736 \\
(0.473)\end{array}$ & $\begin{array}{l}0.713 \\
(0.472)\end{array}$ & $\begin{array}{l}0.301 \\
(0.377)\end{array}$ & $\begin{array}{l}0.244 \\
(0.377)\end{array}$ & $\begin{array}{l}0.286 \\
(0.378)\end{array}$ & $\begin{array}{l}0.245 \\
(0.376)\end{array}$ \\
\hline Prop. male wage earners & $\begin{array}{l}0.231 \\
(0.333)\end{array}$ & $\begin{array}{l}0.322 \\
(0.325)\end{array}$ & $\begin{array}{l}0.316 \\
(0.326)\end{array}$ & $\begin{array}{l}0.213 \\
(0.333)\end{array}$ & $\begin{array}{l}0.633 * * \\
(0.316)\end{array}$ & $\begin{array}{l}0.704 * * \\
(0.313)\end{array}$ & $\begin{array}{l}0.675^{* *} \\
(0.315)\end{array}$ & $\begin{array}{l}0.645^{* *} \\
(0.316)\end{array}$ \\
\hline Value of assets & $\begin{array}{l}-1.044^{* * *} \\
(0.463)\end{array}$ & $\begin{array}{l}-1.087 * * \\
(0.462) \\
\end{array}$ & $\begin{array}{l}-1.072^{* *} \\
(0.461) \\
\end{array}$ & $\begin{array}{l}-1.078 * * \\
(0.464)\end{array}$ & $\begin{array}{l}-1.266 * * * \\
(0.434)\end{array}$ & $\begin{array}{l}-1.342^{* * *} \\
(0.432)\end{array}$ & $\begin{array}{l}-1.259 * * * \\
(0.433)\end{array}$ & $\begin{array}{l}-1.317 * * * \\
(0.433)\end{array}$ \\
\hline \multicolumn{9}{|c|}{ COMMUNITY-LEVEL VARIABLES } \\
\hline School in the village & $\begin{array}{l}-0.126 * * * \\
(0.033)\end{array}$ & $\begin{array}{l}-0.128^{* * *} \\
(0.033)\end{array}$ & $\begin{array}{l}-0.126 * * * \\
(0.033)\end{array}$ & $\begin{array}{l}-0.125^{* * *} \\
(0.033)\end{array}$ & $\begin{array}{l}-0.133^{* * *} \\
(0.032)\end{array}$ & $\begin{array}{l}-0.129 * * * \\
(0.031)\end{array}$ & $\begin{array}{l}-0.127 * * * \\
(0.031)\end{array}$ & $\begin{array}{l}-0.131 \text { *** } \\
(0.031)\end{array}$ \\
\hline Population density & $\begin{array}{l}-0.029 * * \\
(0.011)\end{array}$ & $\begin{array}{l}-0.030 * * * \\
(0.011)\end{array}$ & $\begin{array}{l}-0.030 \text { *** } \\
(0.011)\end{array}$ & $\begin{array}{l}-0.030 \text { *** } \\
(0.011)\end{array}$ & $\begin{array}{l}-0.025^{* *} \\
(0.011)\end{array}$ & $\begin{array}{l}-0.030 * * * \\
(0.011)\end{array}$ & $\begin{array}{l}-0.029 * * * \\
(0.011)\end{array}$ & $\begin{array}{l}-0.028 * * \\
(0.011)\end{array}$ \\
\hline Distance to town & $\begin{array}{l}2.020 * * * \\
(0.640)\end{array}$ & $\begin{array}{l}1.923 * * * \\
(0.639)\end{array}$ & $\begin{array}{l}1.944 * * * \\
(0.638)\end{array}$ & $\begin{array}{l}1.978^{* * *} \\
(0.640)\end{array}$ & $\begin{array}{l}1.102 * \\
(0.667)\end{array}$ & $\begin{array}{l}0.896 \\
(0.665)\end{array}$ & $\begin{array}{l}1.095^{*} \\
(0.664)\end{array}$ & $\begin{array}{l}0.949 \\
(0.666)\end{array}$ \\
\hline Time to all-weather road & $\begin{array}{l}-0.202^{* * *} \\
(0.078)\end{array}$ & $\begin{array}{l}-0.183^{* *} \\
(0.075)\end{array}$ & $\begin{array}{l}-0.169 * * \\
(0.081)\end{array}$ & $\begin{array}{l}-0.186^{* *} \\
(0.084)\end{array}$ & $\begin{array}{l}0.138 * \\
(0.075)\end{array}$ & $\begin{array}{l}0.133^{*} \\
(0.073)\end{array}$ & $\begin{array}{l}0.149 * \\
(0.078)\end{array}$ & $\begin{array}{l}0.165 * * \\
(0.080)\end{array}$ \\
\hline T. to limited cons. Market & $\begin{array}{l}0.164 * \\
(0.093)\end{array}$ & & & $\begin{array}{l}0.158 * \\
(0.093)\end{array}$ & $\begin{array}{l}0.180 * * \\
(0.089)\end{array}$ & & & $\begin{array}{l}0.175^{*} \\
(0.090)\end{array}$ \\
\hline Time to periodic market & & $\begin{array}{l}0.489 * * * \\
(0.054)\end{array}$ & & $\begin{array}{l}0.480 * * * \\
(0.054)\end{array}$ & & $\begin{array}{l}0.310 * * * \\
(0.093)\end{array}$ & & $\begin{array}{l}0.313^{* * *} \\
(0.094)\end{array}$ \\
\hline Time to cooperative market & & & $\begin{array}{l}-0.123 \\
(0.092)\end{array}$ & $\begin{array}{l}-0.084 \\
(0.099)\end{array}$ & & & $\begin{array}{l}-0.041 \\
(0.083)\end{array}$ & $\begin{array}{l}-0.046 \\
(0.083)\end{array}$ \\
\hline $\begin{array}{l}\text { DISTRICT FIXED EFFECTS } \\
\text { MONTH OF SURVEY }\end{array}$ & $\begin{array}{l}Y E S \\
Y E S\end{array}$ & $\begin{array}{l}Y E S \\
Y E S\end{array}$ & $\begin{array}{l}Y E S \\
Y E S\end{array}$ & $\begin{array}{l}Y E S \\
Y E S\end{array}$ & $\begin{array}{l}Y E S \\
Y E S\end{array}$ & $\begin{array}{l}Y E S \\
Y E S\end{array}$ & $\begin{array}{l}\text { YES } \\
\text { YES }\end{array}$ & $\begin{array}{l}\text { YES } \\
\text { YES }\end{array}$ \\
\hline Observations & 4,755 & 4,803 & 4,797 & 4,755 & 4,699 & 4,754 & 4,748 & 4,699 \\
\hline Wald chi2 & 599.9 & 615.2 & 609.9 & 604.1 & 681.2 & 685.7 & 687.1 & 683.4 \\
\hline
\end{tabular}

Notes: Standard errors in parenthesis, * significant at $10 \%$; ** significant at $5 \%$; *** significant at $1 \%$ 
Table 11. Cragg's double-hurdle model of hours of economic activity (Marginal effects)

\begin{tabular}{|c|c|c|c|c|c|c|c|c|}
\hline & \multicolumn{4}{|c|}{ Boys } & \multicolumn{4}{|c|}{ Girls } \\
\hline & (i) & (ii) & (iii) & (iv) & (i) & (ii) & (iii) & (iv) \\
\hline \multicolumn{9}{|l|}{ CHILD CHARACTERISTICS } \\
\hline Child's age & $\begin{array}{c}0.930 * * * \\
(0.074)\end{array}$ & $\begin{array}{c}0.919 * * * \\
(0.073)\end{array}$ & $\begin{array}{c}0.922 * * * \\
(0.073)\end{array}$ & $\begin{array}{c}0.928 * * * \\
(0.074)\end{array}$ & $\begin{array}{c}1.015^{* * *} \\
(0.066)\end{array}$ & $\begin{array}{c}1.023^{* * *} \\
(0.066)\end{array}$ & $\begin{array}{c}1.020 * * * \\
(0.066)\end{array}$ & $\begin{array}{c}0.928 * * * \\
(0.074)\end{array}$ \\
\hline Age Squared & $\begin{array}{c}-0.037 * * * \\
(0.004)\end{array}$ & $\begin{array}{c}-0.036^{* * *} \\
(0.004)\end{array}$ & $\begin{array}{c}-0.037 * * * \\
(0.004)\end{array}$ & $\begin{array}{c}-0.037 * * * \\
(0.004)\end{array}$ & $\begin{array}{c}-0.039 * * * \\
(0.003)\end{array}$ & $\begin{array}{c}-0.039 * * * \\
(0.003)\end{array}$ & $\begin{array}{c}-0.039 * * * \\
(0.003)\end{array}$ & $\begin{array}{c}-0.037 * * * \\
(0.004)\end{array}$ \\
\hline Mother in the household & $\begin{array}{c}-0.269 * * * \\
(0.061)\end{array}$ & $\begin{array}{c}-0.278^{* * *} \\
(0.060)\end{array}$ & $\begin{array}{c}-0.276^{* * *} \\
(0.060)\end{array}$ & $\begin{array}{c}-0.270^{* * *} \\
(0.061)\end{array}$ & $\begin{array}{c}-0.179 * * * \\
(0.056)\end{array}$ & $\begin{array}{c}-0.179 * * * \\
(0.056)\end{array}$ & $\begin{array}{c}-0.183^{* * *} \\
(0.056)\end{array}$ & $\begin{array}{c}-0.270^{* * *} \\
(0.061)\end{array}$ \\
\hline \multicolumn{9}{|c|}{ HOUSEHOLD CHARACTERISTICS } \\
\hline Dependency ratio & $\begin{array}{c}0.230 \\
(0.195)\end{array}$ & $\begin{array}{c}0.274 \\
(0.195)\end{array}$ & $\begin{array}{c}0.261 \\
(0.195)\end{array}$ & $\begin{array}{c}0.247 \\
(0.195)\end{array}$ & $\begin{array}{c}0.465^{* *} \\
(0.188)\end{array}$ & $\begin{array}{c}0.425^{* *} \\
(0.188)\end{array}$ & $\begin{array}{c}0.447 * * \\
(0.188)\end{array}$ & $\begin{array}{c}0.247 \\
(0.195)\end{array}$ \\
\hline Age of the head in years & $\begin{array}{l}-0.004 * \\
(0.002)\end{array}$ & $\begin{array}{c}-0.004^{* *} \\
(0.002)\end{array}$ & $\begin{array}{c}-0.004^{* *} \\
(0.002)\end{array}$ & $\begin{array}{l}-0.004 * \\
(0.002)\end{array}$ & $\begin{array}{c}-0.006^{* * *} \\
(0.002)\end{array}$ & $\begin{array}{c}-0.006 * * * \\
(0.002)\end{array}$ & $\begin{array}{c}-0.006 * * * \\
(0.002)\end{array}$ & $\begin{array}{l}-0.004 * \\
(0.002)\end{array}$ \\
\hline Head is female & $\begin{array}{l}-0.085 \\
(0.065)\end{array}$ & $\begin{array}{c}-0.094 \\
(0.064)\end{array}$ & $\begin{array}{l}-0.090 \\
(0.064)\end{array}$ & $\begin{array}{l}-0.089 \\
(0.065)\end{array}$ & $\begin{array}{c}-0.005 \\
(0.058)\end{array}$ & $\begin{array}{c}-0.010 \\
(0.058)\end{array}$ & $\begin{array}{l}-0.013 \\
(0.058)\end{array}$ & $\begin{array}{l}-0.089 \\
(0.065)\end{array}$ \\
\hline Prop.of adults $>$ sec. sch & $\begin{array}{c}-0.124 * * \\
(0.058)\end{array}$ & $\begin{array}{c}-0.130 * * \\
(0.057)\end{array}$ & $\begin{array}{c}-0.126^{* *} \\
(0.058)\end{array}$ & $\begin{array}{c}-0.125 * * \\
(0.058)\end{array}$ & $\begin{array}{c}-0.301 * * * \\
(0.055)\end{array}$ & $\begin{array}{c}-0.311^{* * *} \\
(0.055)\end{array}$ & $\begin{array}{c}-0.302 * * * \\
(0.055)\end{array}$ & $\begin{array}{c}-0.125 * * \\
(0.058)\end{array}$ \\
\hline Hh involved in farming & $\begin{array}{l}-0.062 \\
(0.079)\end{array}$ & $\begin{array}{l}-0.059 \\
(0.078)\end{array}$ & $\begin{array}{l}-0.060 \\
(0.078)\end{array}$ & $\begin{array}{l}-0.061 \\
(0.079)\end{array}$ & $\begin{array}{l}-0.083 \\
(0.071)\end{array}$ & $\begin{array}{l}-0.075 \\
(0.071)\end{array}$ & $\begin{array}{l}-0.089 \\
(0.071)\end{array}$ & $\begin{array}{l}-0.061 \\
(0.079)\end{array}$ \\
\hline Hh .non-farm enterprises & $\begin{array}{l}-0.101 \\
(0.104)\end{array}$ & $\begin{array}{l}-0.105 \\
(0.103)\end{array}$ & $\begin{array}{l}-0.103 \\
(0.103)\end{array}$ & $\begin{array}{l}-0.104 \\
(0.104)\end{array}$ & $\begin{array}{c}-0.263^{* * *} \\
(0.095)\end{array}$ & $\begin{array}{c}-0.249 * * * \\
(0.095)\end{array}$ & $\begin{array}{c}-0.264^{* * *} \\
(0.095)\end{array}$ & $\begin{array}{l}-0.104 \\
(0.104)\end{array}$ \\
\hline Prop. fem wage earners & $\begin{array}{l}-0.126 \\
(0.791)\end{array}$ & $\begin{array}{l}-0.177 \\
(0.791)\end{array}$ & $\begin{array}{l}-0.139 \\
(0.791)\end{array}$ & $\begin{array}{l}-0.180 \\
(0.790)\end{array}$ & $\begin{array}{c}-0.722 \\
(0.626)\end{array}$ & $\begin{array}{l}-0.729 \\
(0.626)\end{array}$ & $\begin{array}{l}-0.748 \\
(0.626)\end{array}$ & $\begin{array}{l}-0.180 \\
(0.790)\end{array}$ \\
\hline Prop. male wage earners & $\begin{array}{c}-1.529 * * * \\
(0.583)\end{array}$ & $\begin{array}{c}-1.454^{* *} \\
(0.575)\end{array}$ & $\begin{array}{c}-1.435^{* *} \\
(0.576)\end{array}$ & $\begin{array}{c}-1.566 * * * \\
(0.583)\end{array}$ & $\begin{array}{c}0.017 \\
(0.521)\end{array}$ & $\begin{array}{c}0.109 \\
(0.518)\end{array}$ & $\begin{array}{c}0.040 \\
(0.518)\end{array}$ & $\begin{array}{c}-1.566 * * * \\
(0.583)\end{array}$ \\
\hline Value of assets & $\begin{array}{c}-3.139 * * * \\
(0.788) \\
\end{array}$ & $\begin{array}{c}-3.211^{* * *} \\
(0.786) \\
\end{array}$ & $\begin{array}{c}-3.111^{* * *} \\
(0.785) \\
\end{array}$ & $\begin{array}{c}-3.229 * * * \\
(0.789) \\
\end{array}$ & $\begin{array}{c}-3.679 * * * \\
(0.691) \\
\end{array}$ & $\begin{array}{c}-3.494 * * * \\
(0.696) \\
\end{array}$ & $\begin{array}{c}-3.412^{* * *} \\
(0.695) \\
\end{array}$ & $\begin{array}{c}-3.229 * * * \\
(0.789) \\
\end{array}$ \\
\hline \multicolumn{9}{|c|}{ COMMUNITY-LEVEL VARIABLES } \\
\hline School in the village & $\begin{array}{c}0.003 \\
(0.054)\end{array}$ & $\begin{array}{c}0.000 \\
(0.054)\end{array}$ & $\begin{array}{c}0.003 \\
(0.054)\end{array}$ & $\begin{array}{c}0.002 \\
(0.054)\end{array}$ & $\begin{array}{c}0.038 \\
(0.050)\end{array}$ & $\begin{array}{c}0.045 \\
(0.049)\end{array}$ & $\begin{array}{c}0.051 \\
(0.049)\end{array}$ & $\begin{array}{c}0.002 \\
(0.054)\end{array}$ \\
\hline Population density & $\begin{array}{l}-0.022 \\
(0.019)\end{array}$ & $\begin{array}{l}-0.025 \\
(0.019)\end{array}$ & $\begin{array}{l}-0.023 \\
(0.019)\end{array}$ & $\begin{array}{l}-0.025 \\
(0.019)\end{array}$ & $\begin{array}{c}0.003 \\
(0.019)\end{array}$ & $\begin{array}{l}-0.004 \\
(0.018)\end{array}$ & $\begin{array}{l}-0.004 \\
(0.018)\end{array}$ & $\begin{array}{l}-0.025 \\
(0.019)\end{array}$ \\
\hline Distance to town & $\begin{array}{c}0.539 \\
(1.103)\end{array}$ & $\begin{array}{c}0.287 \\
(1.103)\end{array}$ & $\begin{array}{c}0.385 \\
(1.102)\end{array}$ & $\begin{array}{c}0.441 \\
(1.104)\end{array}$ & $\begin{array}{l}2.065^{* *} \\
(1.037)\end{array}$ & $\begin{array}{l}1.735^{*} \\
(1.041)\end{array}$ & $\begin{array}{l}1.915^{*} \\
(1.036)\end{array}$ & $\begin{array}{c}0.441 \\
(1.104)\end{array}$ \\
\hline Time to all-weather road & $\begin{array}{l}-0.067 \\
(0.129)\end{array}$ & $\begin{array}{l}-0.022 \\
(0.125)\end{array}$ & $\begin{array}{l}-0.016 \\
(0.134)\end{array}$ & $\begin{array}{l}-0.066 \\
(0.138)\end{array}$ & $\begin{array}{c}0.168 \\
(0.117)\end{array}$ & $\begin{array}{l}0.150 \\
(0.115)\end{array}$ & $\begin{array}{c}0.188 \\
(0.123)\end{array}$ & $\begin{array}{l}-0.066 \\
(0.138)\end{array}$ \\
\hline T. to limited cons. Market & $\begin{array}{c}-0.187 * * * \\
(0.050)\end{array}$ & & & $\begin{array}{c}-0.192 * * * \\
(0.050)\end{array}$ & $\begin{array}{c}-0.149 * * \\
(0.072)\end{array}$ & & & $\begin{array}{c}-0.145^{* *} \\
(0.073)\end{array}$ \\
\hline T. to periodic market & & $\begin{array}{c}-0.117 * * \\
(0.053)\end{array}$ & & $\begin{array}{c}-0.123 * * \\
(0.053)\end{array}$ & & $\begin{array}{l}-0.219 * \\
(0.124)\end{array}$ & & $\begin{array}{l}-0.233^{*} \\
(0.124)\end{array}$ \\
\hline T. to cooperative market & & & $\begin{array}{l}-0.039 \\
(0.104)\end{array}$ & $\begin{array}{l}-0.062 \\
(0.104)\end{array}$ & & & $\begin{array}{l}-0.031 \\
(0.124)\end{array}$ & $\begin{array}{l}-0.015 \\
(0.124)\end{array}$ \\
\hline $\begin{array}{l}\text { DISTRICT FIXED EFFECTS } \\
\text { MONTH OF SURVEY }\end{array}$ & $\begin{array}{l}Y E S \\
Y E S\end{array}$ & $\begin{array}{l}\text { YES } \\
\text { YES }\end{array}$ & & $\begin{array}{l}Y E S \\
Y E S\end{array}$ & $\begin{array}{l}\text { YES } \\
\text { YES }\end{array}$ & $\begin{array}{l}\text { YES } \\
\text { YES }\end{array}$ & $\begin{array}{l}Y E S \\
Y E S\end{array}$ & $\begin{array}{l}Y E S \\
Y E S\end{array}$ \\
\hline $\begin{array}{l}\text { Observations } \\
\text { Wald Chi } 2\end{array}$ & $\begin{array}{c}4,755 \\
0.0534\end{array}$ & $\begin{array}{c}4,803 \\
0.0537\end{array}$ & $\begin{array}{c}4,797 \\
0.0534\end{array}$ & $\begin{array}{c}4,755 \\
0.0538\end{array}$ & $\begin{array}{c}4,699 \\
0.0726\end{array}$ & $\begin{array}{c}4,754 \\
0.0722\end{array}$ & $\begin{array}{c}4,748 \\
0.0723\end{array}$ & $\begin{array}{c}4,755 \\
0.0538\end{array}$ \\
\hline
\end{tabular}

Notes: Standard errors in parenthesis, * significant at $10 \%$; ** significant at $5 \%$; *** significant at $1 \%$ 
Table 12. Cragg's double-hurdle model for different child ages (Marginal effects)

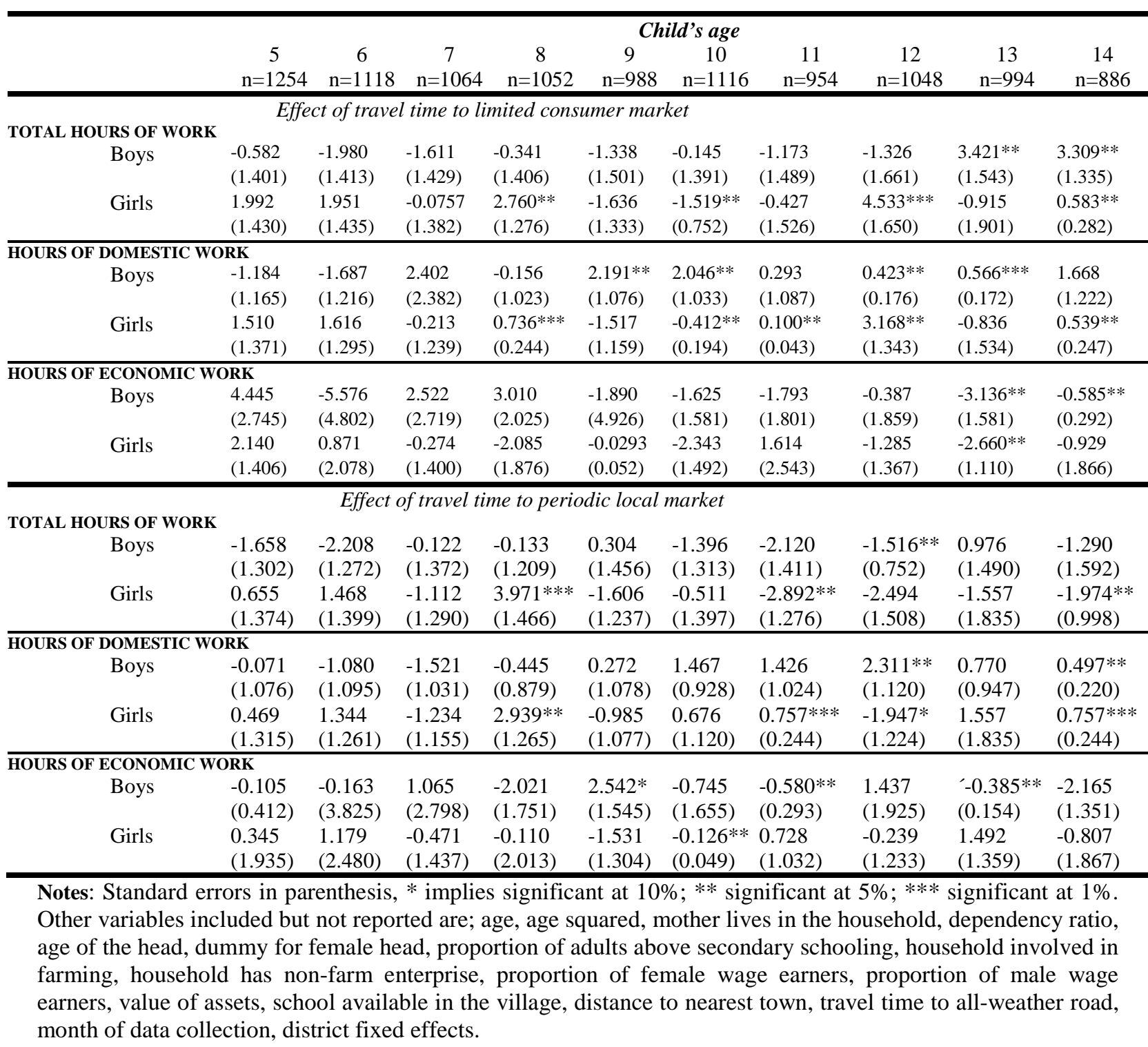


Table 13. Probit regressions for distance to market (Marginal effects)

\begin{tabular}{cccc}
\hline & Ltd consumer market & Periodic market & Cooperative market \\
\hline DOMESTIC ACTIVITY & & & $-0.146^{* *}$ \\
Boys & 0.118 & -0.211 & $(0.046)$ \\
& $(0.104)$ & $(0.138)$ & -0.029 \\
Girls & 0.026 & -0.014 & $(0.027)$ \\
\hline ECONOMIC ACTIVITY & $(0.083)$ & $(0.087)$ & $-0.302^{* *}$ \\
Boys & & & $(0.093)$ \\
Girls & 0.039 & $-0.135^{*}$ & 0.152 \\
& $(0.049)$ & $(0.061)$ & $(0.102)$ \\
\hline
\end{tabular}

Notes: Standard errors in parenthesis, * implies significant at 10\%; ** significant at 5\%; *** significant at $1 \%$. Other variables included but not reported are; age, age squared, mother lives in the household, dependency ratio, age of the head, dummy for female head, proportion of adults above secondary schooling, household involved in farming, household has non-farm enterprise, proportion of female wage earners, proportion of male wage earners, value of assets, school available in the village, distance to nearest town, travel time to all-weather road, month of data collection, district fixed effects.

Table 14. Double-hurdle model for distance to market (Marginal effects)

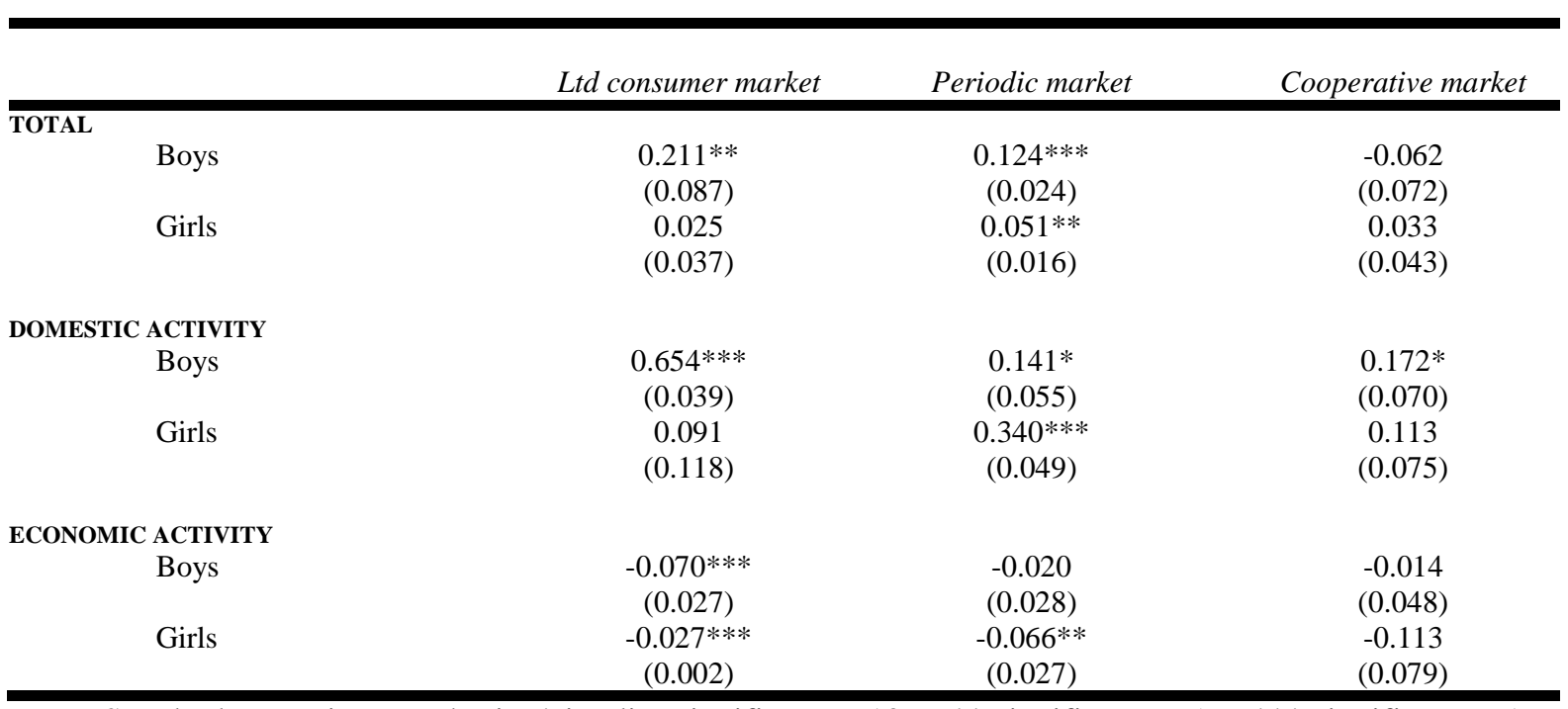

Notes: Standard errors in parenthesis, * implies significant at 10\%; ** significant at 5\%; *** significant at $1 \%$. Other variables included but not reported are; age, age squared, mother lives in the household, dependency ratio, age of the head, dummy for female head, proportion of adults above secondary schooling, household involved in farming, household has non-farm enterprise, proportion of female wage earners, proportion of male wage earners, value of assets, school available in the village, distance to nearest town, travel time to all-weather road, month of data collection, district fixed effects. 
Table 15. Probit regressions for actual location of markets (Marginal effects)

\begin{tabular}{|c|c|c|c|c|}
\hline \multirow[b]{3}{*}{ Market proxies } & \multicolumn{4}{|c|}{ Dependent variables } \\
\hline & \multicolumn{2}{|c|}{ Domestic activity } & \multicolumn{2}{|c|}{ Economic activity } \\
\hline & Boys & Girls & Boys & Girls \\
\hline LIMITED CONSUMER MARKET & & & & \\
\hline At the trading center & $\begin{array}{l}-0.010 \\
(0.016)\end{array}$ & $\begin{array}{c}-0.011 \\
(0.025)\end{array}$ & $\begin{array}{c}0.104 \\
(0.066)\end{array}$ & $\begin{array}{l}-0.027 \\
(0.022)\end{array}$ \\
\hline At district \& beyond & $\begin{array}{c}-0.002 \\
(0.018) \\
\end{array}$ & $\begin{array}{l}-0.026 \\
(0.024) \\
\end{array}$ & $\begin{array}{c}0.046 \\
(0.109) \\
\end{array}$ & $\begin{array}{l}-0.035 \\
(0.030) \\
\end{array}$ \\
\hline \multicolumn{5}{|l|}{ PERIODIC MARKET } \\
\hline At the trading center & $\begin{array}{c}0.048 * * * \\
(0.016)\end{array}$ & $\begin{array}{c}0.011 \\
(0.065)\end{array}$ & $\begin{array}{l}-0.001 \\
(0.012)\end{array}$ & $\begin{array}{c}0.016 \\
(0.059)\end{array}$ \\
\hline At district \& beyond & $\begin{array}{c}0.039 * * \\
(0.019) \\
\end{array}$ & $\begin{array}{c}0.047 * * \\
(0.019) \\
\end{array}$ & $\begin{array}{c}-0.021 \\
(0.020) \\
\end{array}$ & $\begin{array}{r}-0.129 * * \\
(0.051) \\
\end{array}$ \\
\hline \multicolumn{5}{|l|}{ COOPERATIVE MARKET } \\
\hline At the trading center & $\begin{array}{c}0.012 \\
(0.026)\end{array}$ & $\begin{array}{c}0.066 \\
(0.044)\end{array}$ & $\begin{array}{c}-0.055^{* *} \\
(0.027)\end{array}$ & $\begin{array}{c}0.003 \\
(0.022)\end{array}$ \\
\hline At district \& beyond & $\begin{array}{c}0.021 \\
(0.038) \\
\end{array}$ & $\begin{array}{c}0.030 \\
(0.051) \\
\end{array}$ & $\begin{array}{l}-0.023 \\
(0.031) \\
\end{array}$ & $\begin{array}{l}-0.053 \\
(0.039) \\
\end{array}$ \\
\hline
\end{tabular}

Notes: Reference category: market located in the village or nearby. Rows represent market proxies, Standard errors in parenthesis, * implies significant at $10 \%$; ** significant at $5 \%$; *** significant at $1 \%$. Other variables included but not reported are; age, age squared, mother lives in the household, dependency ratio, age of the head, dummy for female head, proportion of adults above secondary schooling, household involved in farming, household has non-farm enterprise, proportion of female wage earners, proportion of male wage earners, value of assets, school available in the village, distance to nearest town, travel time to all-weather road, month of data collection, district fixed effects.

Table 16. Double hurdle model for actual location of the market (Marginal effects)

\begin{tabular}{|c|c|c|c|c|c|c|}
\hline & \multicolumn{2}{|c|}{ Total } & \multicolumn{2}{|c|}{$\begin{array}{c}\text { Hours of work } \\
\text { Domestic activity }\end{array}$} & \multicolumn{2}{|c|}{ Economic activity } \\
\hline & Boys & Girls & Boy s & Girls & Boy s & Girls \\
\hline \multicolumn{7}{|c|}{ LIMITED CONSUMER MARKET } \\
\hline At the trading center & $\begin{array}{c}0.003 * * \\
(0.001)\end{array}$ & $\begin{array}{c}0.012 \\
(0.038)\end{array}$ & $\begin{array}{c}0.002^{* *} \\
(0.001)\end{array}$ & $\begin{array}{c}-0.098 \\
(0.064)\end{array}$ & $\begin{array}{l}-0.017 \\
(0.081)\end{array}$ & $\begin{array}{l}-0.621 \\
(0.443)\end{array}$ \\
\hline At district \& beyond & $\begin{array}{c}0.118 \\
(0.081) \\
\end{array}$ & $\begin{array}{c}0.026 \\
(0.059) \\
\end{array}$ & $\begin{array}{c}-0.028 \\
(0.028) \\
\end{array}$ & $\begin{array}{c}0.051 \\
(0.077) \\
\end{array}$ & $\begin{array}{c}-0.038 \\
(0.069) \\
\end{array}$ & $\begin{array}{c}-0.152 * * \\
(0.060) \\
\end{array}$ \\
\hline \multicolumn{7}{|l|}{ PERIODIC MARKET } \\
\hline At the trading center & $\begin{array}{c}0.061 \\
(0.046)\end{array}$ & $\begin{array}{c}0.042 * * \\
(0.018)\end{array}$ & $\begin{array}{c}0.157 * * * \\
(0.052)\end{array}$ & $\begin{array}{c}0.040 \\
(0.073)\end{array}$ & $\begin{array}{c}-0.149 * * \\
(0.059)\end{array}$ & $\begin{array}{c}0.049 \\
(0.047)\end{array}$ \\
\hline At district \& beyond & $\begin{array}{c}0.024 \\
(0.081) \\
\end{array}$ & $\begin{array}{c}0.151^{* *} \\
(0.059) \\
\end{array}$ & $\begin{array}{c}0.105 \\
(0.077) \\
\end{array}$ & $\begin{array}{l}1.009^{* *} \\
(0.404) \\
\end{array}$ & $\begin{array}{c}-0.014 \\
(0.056) \\
\end{array}$ & $\begin{array}{c}0.029 \\
(0.045) \\
\end{array}$ \\
\hline \multicolumn{7}{|l|}{ COOPERATIVE MARKET } \\
\hline At the trading center & $\begin{array}{c}0.252 \\
(0.477)\end{array}$ & $\begin{array}{c}0.145 * * \\
(0.059)\end{array}$ & $\begin{array}{c}0.132 * * * \\
(0.024)\end{array}$ & $\begin{array}{c}0.035 \\
(0.045)\end{array}$ & $\begin{array}{c}-0.139 * * * \\
(0.044)\end{array}$ & $\begin{array}{c}-0.080 * * * \\
(0.016)\end{array}$ \\
\hline At district \& beyond & $\begin{array}{c}0.017 \\
(0.055)\end{array}$ & $\begin{array}{c}-0.024 \\
(0.081)\end{array}$ & $\begin{array}{c}0.026 \\
(0.059)\end{array}$ & $\begin{array}{c}0.013 \\
(0.060)\end{array}$ & $\begin{array}{c}0.011 \\
(0.037)\end{array}$ & $\begin{array}{c}0.115 \\
(0.089)\end{array}$ \\
\hline
\end{tabular}

Notes: Reference category: market located in the village or nearby. Rows represent market proxies, Standard errors in parenthesis, * implies significant at $10 \%$; ** significant at 5\%; *** significant at $1 \%$. Other variables included but not reported are; age, age squared, mother lives in the household, dependency ratio, age of the head, dummy for female head, proportion of adults above secondary schooling, household involved in farming, household has non-farm enterprise, proportion of female wage earners, proportion of male wage earners, value of assets, school available in the village, distance to nearest town, travel time to all-weather road, month of data collection, district fixed effects. 